\title{
Assessment of climate variations in temperature and precipitation extreme events over Iran
}

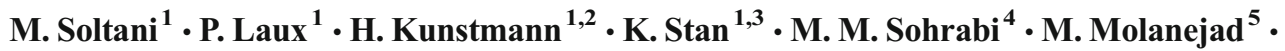 \\ A. A. Sabziparvar ${ }^{6}$ A. Ranjbar SaadatAbadi ${ }^{7}$ - F. $\operatorname{Ranjbar}^{8} \cdot$ I. Rousta $^{8}$. \\ P. Zawar-Reza ${ }^{9}$ F. Khoshakhlagh $^{8}$ • I. Soltanzadeh ${ }^{10}$ • C. A. Babu ${ }^{11}$ - G. H. Azizi ${ }^{8}$. \\ M. V. Martin ${ }^{12}$
}

Received: 26 March 2014 / Accepted: 23 July 2015 / Published online: 1 September 2015

(C) The Author(s) 2015. This article is published with open access at Springerlink.com

\begin{abstract}
In this study, changes in the spatial and temporal patterns of climate extreme indices were analyzed. Daily maximum and minimum air temperature, precipitation, and their association with climate change were used as the basis for tracking changes at 50 meteorological stations in Iran over the period 1975-2010. Sixteen indices of extreme temperature and 11 indices of extreme precipitation, which have been quality controlled and tested for homogeneity and missing data, are examined. Temperature extremes show a warming trend, with a large proportion of stations having statistically significant trends for all temperature indices. Over the last 15 years (1995-2010), the annual frequency of warm days and nights has increased by 12 and 14 days/decade, respectively. The number of cold days and nights has decreased by 4 and 3 days/decade, respectively. The annual mean maximum and minimum temperatures averaged across Iran both increased by 0.031 and $0.059^{\circ} \mathrm{C} /$ decade. The probability of cold nights has gradually decreased from more than $20 \%$ in 1975-1986 to less
\end{abstract}

M. Soltani

mohsen.soltani@kit.edu

1 Institute of Meteorology and Climate Research, Karlsruhe Institute of Technology, 82467 Garmisch-Partenkirchen, Germany

2 Department of Geography, University of Augsburg, Augsburg, Germany

3 Department of Earth and Atmospheric Sciences, University of Alberta, Edmonton, Alberta, Canada

4 Department of Biological and Agricultural Engineering, University of Idaho, Boise, ID 83702, USA

5 Research Institute for New Technology Development Studies (RINTDS), Iranian Research Organization for Science \& Technology, Tehran, Iran

6 Department of Irrigation and Drainage, Faculty of Agriculture, Bu-Ali Sina University, Hamedan, Iran than $15 \%$ in 1999-2010, whereas the mean frequency of warm days has increased abruptly between the first 12 -year period (1975-1986) and the recent 12-year period (1999-2010) from 18 to $40 \%$, respectively. There are no systematic regional trends over the study period in total precipitation or in the frequency and duration of extreme precipitation events. Statistically significant trends in extreme precipitation events are observed at less than $15 \%$ of all weather stations, with no spatially coherent pattern of change, whereas statistically significant changes in extreme temperature events have occurred at more than $85 \%$ of all weather stations, forming strongly coherent spatial patterns.

\section{Introduction}

Changes in extreme weather and climate events have significant impacts and pose serious challenges to societies (CCSP

7 Atmospheric Sciences and Meteorological Research Center (ASMERC), I.R. of Iran Meteorological Organization (IRIMO), Tehran, Iran

8 Department of Physical Geography, Faculty of Geography, University of Tehran, Tehran, Iran

9 Department of Geography, University of Canterbury, Christchurch, New Zealand

10 Meteorological Service of New Zealand (MetService), Wellington, New Zealand

11 Department of Atmospheric Sciences, Cochin University of Science and Technology, Cochin 682 016, India

12 Centre for Oceans, Rivers, Atmosphere and Land Sciences (CORAL), Indian Institute of Technology Kharagpur, Kharagpur, India 
2008). Such extremes are likely to have profound impacts on human societies (e.g., Zhang et al. 2005) and can lead to hundreds of injuries and fatalities and billions of dollars of economic losses. Climate extremes, as defined by the World Meteorological Organization (WMO), are rare meteorological and climatological phenomena that surpass a defined threshold (Das et al. 2003). Extreme events fall in the tails of a probability distribution of climate parameters, such as rainfall and temperature. Changes in the frequency of temperature extremes may result in changes of the mean, the variance, and/or both. In a skewed distribution such as that of precipitation, changes in the distribution mean often affect its variability or spread. Climate change may alter the frequency of precipitation, which consequently also leads to changes in length of dry spells.

Understanding the mechanisms associated with extreme events at the regional scale could provide useful insights for resource planners, system managers, and policy makers to help to mitigate financial losses; therefore, comprehensive regional studies are crucial to assess the mechanisms and impacts of extreme events in a global context. Prior research has shown changes in the frequency and intensity of climate extremes over the past century (Alexander et al. 2006; Dos Santos et al. 2010; Frei and Schär 2001; Frich et al. 2002; Kiktev et al. 2003; Moberg and Jones 2005; Sen Roy and Balling 2004; Vincent et al. 2005; Aguilar et al. 2005; New et al. 2006; Wong et al. 2010; Hirschi et al. 2011). Zong and Chen (2000) illustrated how devastating a single extreme precipitation event can be for human societies. Increases in the intensity and frequency of extreme temperature events can result in human health issues along with significant increase in energy consumption (e.g., Huynen et al. 2001; UNEP 2004). Numerous studies about changes of extremes have been published (Alexander et al. 2006; Frei and Schär 2001; Karl and Knight 1998; Osborn et al. 2000; Sen Roy and Balling 2004), but there is still a considerable lack of information on trends and changeability in daily climate and climate extremes (e.g., Nicholls et al. 1996). Synthesizing the results of those studies to obtain a more regional and global picture is an ongoing progress (Alexander et al. 2006; Frich et al. 2002; Groisman et al. 1999; Karl et al. 1995; Kiktev et al. 2003; Moberg and Jones 2005; Kharin et al. 2007; Peterson et al. 2008).

Klein Tank and Können (2003) evaluated the trends in indices of daily temperature and precipitation extremes in Europe over 1946-1999. The results of this study indicated that for the 1946-1975 subperiod, an episode of slight cooling, the annual number of warm extremes decreased, but the annual number of cold extremes did not increase. For the 1976-1999 subperiod, an episode of pronounced warming, the annual number of warm extremes increased two times faster than expected from the corresponding decrease in the number of cold extremes. For precipitation, all the continental-averaged (Europe) indices of wet extremes increased in the 1946-1999 period, although the spatial coherence of the trends was low. Such trend studies have been performed also for European countries individually. Domonkos (2001) studied consecutive days that have extremely low and extremely high temperatures (long periods, i.e., several weeks) in Hungary. Jones et al. (1999) used definite temperatures, apart from the values of the 90 and $10 \%$ intervals, as threshold values to study the change in the frequency of temperature extremes over the British Isles. For the winter season, the number of days and the sum of degree-days with temperatures below $0{ }^{\circ} \mathrm{C}$ were determined, while for the summer, these were determined with temperatures above $20^{\circ} \mathrm{C}$.

Climate trends in indices for temperature and precipitation across New York State during 1948-2008 were investigated by Insaf et al. (2012). Their results showed that the most substantial change per decade is related to the number of frost days $(-0.97$ days per decade) and diurnal temperature $\left(-0.11{ }^{\circ} \mathrm{C}\right)$. For precipitation indicators, the number of heavy precipitation days (+0.99 days), consecutive wet days $(+0.42$ days $)$, the total wet day precipitation $(+30.19 \mathrm{~mm})$, and the simple daily intensity index (+ $0.18 \mathrm{~mm} /$ day) showed the most pronounced changes per decade. Brunetti et al. (2000) showed positive trends for both maximum and minimum daily temperature over the period 1865-1996 in Italy, and they pointed out that the trends are greatest in the south of the country, while Moonen et al. (2002) demonstrated decreases in extreme cold events in central Italy. Kioutsioukis et al. (2010) assessed statistical changes in climate extremes over Greece and found that half of the examined climatic indices exhibited significant regional trends.

For the southern hemisphere, Alexander et al. (2007), using a standard set of annual and seasonal climate extreme indices derived from daily temperature and precipitation data, analyzed the relationships between mean and extreme trends across Australia and found that the trends in extremes of both temperature and precipitation are highly correlated with the mean trends. Plummer et al. (1999) studied climate extremes in Australia and New Zealand during the twentieth century and found increases in heavy precipitation events, enhanced frequency of extreme warm days and nights, while extreme cold days and nights and drought events had decreased. Similar results were produced by Manton et al. (2001) in a study over Southeast Asia and the South Pacific islands including Australia and New Zealand. Souvignet et al. (2014) studied the recent climatic trends and their linkages to river discharge in Central Vietnam. They found an intensification of rainfall $(+15 \% /$ decade $)$, with more extreme and longer events. River discharge trends also showed an increase in mean discharge (31 to $35 \% /$ decade) over the last decades. 
Meanwhile, for both northern and southern hemispheres at the same time, Choi et al. (2009) evaluated the changes in means and extreme events of temperature and precipitation in the Asia-Pacific Network region during 1955-2007. Their results indicated that there have been seasonally and diurnally asymmetric changes in extreme temperature events relative to recent increases in temperature means in the APN region. Statistically significant trends in extreme precipitation events were observed at fewer than $30 \%$ of all weather stations, with no spatially coherent pattern of change, whereas statistically significant changes in extreme temperature events had occurred at more than $70 \%$ of all weather stations, forming strongly coherent spatial patterns.

For Iran, there are various regional studies on recent trends and variability in the monthly climate conditions (Kavyani and Asakereh 1999; Hedayat Dezfuly 2001; Sabziparvar et al. 2011); however, there is limited work on precipitation and temperature extremes. Alijani (2007) analyzed a time series of daily rainfall variability and extreme events at Tehran station from 1961 to 2004. Sohrabi et al. (2009) detected noticeable changes in temperature and precipitation extremes that can lead to warmer and dryer climate in the Semnan province. The variability of extreme temperature and precipitation events in Iran in recent decades was evaluated by Rahimzadeh et al. (2009), who found negative trends for indices including frost/ice days (FD/ID), cool days/nights (TX10p/TN10p), and diurnal temperature range (DTR) over most regions of Iran. Positive trends were found for summer days (SU25), warm days (TX90p), and tropical nights (TR20) over most regions of the country. Marofi et al. (2010) and Sohrabi et al. $(2013 \mathrm{a}, \mathrm{b})$ found temperature indices that are consistent with a warming in the coastal and mountainous regions, respectively. Warm nights, hot days, and the frequency of their occurrence increased, while cold spell and cool day and night frequencies declined. Taghavi (2010) investigated the linkage between climate change and extreme events in Iran and found that the number of very warm days (T40) increased while the amount of cool days (ID) decreased. Changes in total and extreme precipitation indices vary with geographic location. Sohrabi et al. (2013a) demonstrated the linkage between climate extremes and drought over Idaho, USA, and variations in sea surface temperature and pressure in Pacific and Atlantic Oceans. Their study also reported significant increases in temperature extremes, which can lead to considerable changes in the hydrological cycle of the region.

This study provides a comprehensive analysis of changes (and their significance) in temperature and precipitation extremes across Iran for the period 19752010. Daily to seasonal time scales are assessed in order to predict the impact of climate change on regional hydrology and water resources. Due to recent water shortages in Iran, including reduced water levels of lakes and alteration of major rivers to seasonal rivers, analyses of spatiotemporal changes in climatic extremes can provide crucial information for policy and decision makers.

\section{Methodology}

\subsection{Study area, data, and quality control}

Iran is located to the southwest of Asia, and it is a mostly mountainous country where two major mountain chains, the Alborz Range and the Zagros Range, dissect the country into climactic zones. The Caspian Sea is situated in the northern sector, providing maritime influences, while the south is dominated by the Oman Sea and Persian Gulf. Iran covers approximately $1,873,959 \mathrm{~km}^{2}$ and has a topography range from -26 to $5671 \mathrm{~m}$ a.s.l. (Fig. 1). The coastal Caspian Sea is typically mild, humid, and wet, with air temperature rarely falling below $0{ }^{\circ} \mathrm{C}$ or exceeding $29^{\circ} \mathrm{C}$. Mountainous areas experience severe winters and heavy snowfalls, and the remaining regions are arid, with their humidity and temperature varying based on proximity to major water bodies and topography. January is usually the coldest months with typical temperatures ranging from 0 to $10^{\circ} \mathrm{C}$. The hottest month is July with temperatures upwards of 20 to $30^{\circ} \mathrm{C}$ (Alijani 1996).

In this study, daily maximum and minimum temperature and precipitation data observed at 50 weather stations, collected by the Islamic Republic of Iran Meteorological Organization (IRIMO), are used to analyze 16 extreme temperature indices and 11 extreme precipitation indices for a 36-year (1975-2010) period (Fig. 1 and Table 1). Data quality checks, from Zhang and Yang (2004), are carried out to identify missing values and potentially unrealistic climate records (i.e., outliers).

\subsection{Extreme climate indices and methods of trend analyses}

A set of 27 indices, developed by the Expert Team on Climate Change Detection and Indices (ETCCDMI), is applied to calculate a standard set of extreme statistics for Iran (Easterling et al. 2003). Some indices are based on fixed thresholds, while others are dependent on the location; thresholds are defined as percentiles of the time series distribution (Table 2). Procedures developed by Zhang and Yang (2004) are utilized to develop linear trends, calculated based on climate anomalies between 1975 and 2010, and have been consistently followed in similar studies (e.g., Sohrabi et al. 2013a, b; Marofi et al. 2010; Alexander et al. 2006; Dos Santos et al. 2010; Haylock et al. 2006; Zhang et al. 2005; Easterling et al. 2003; Choi et al. 2009). 


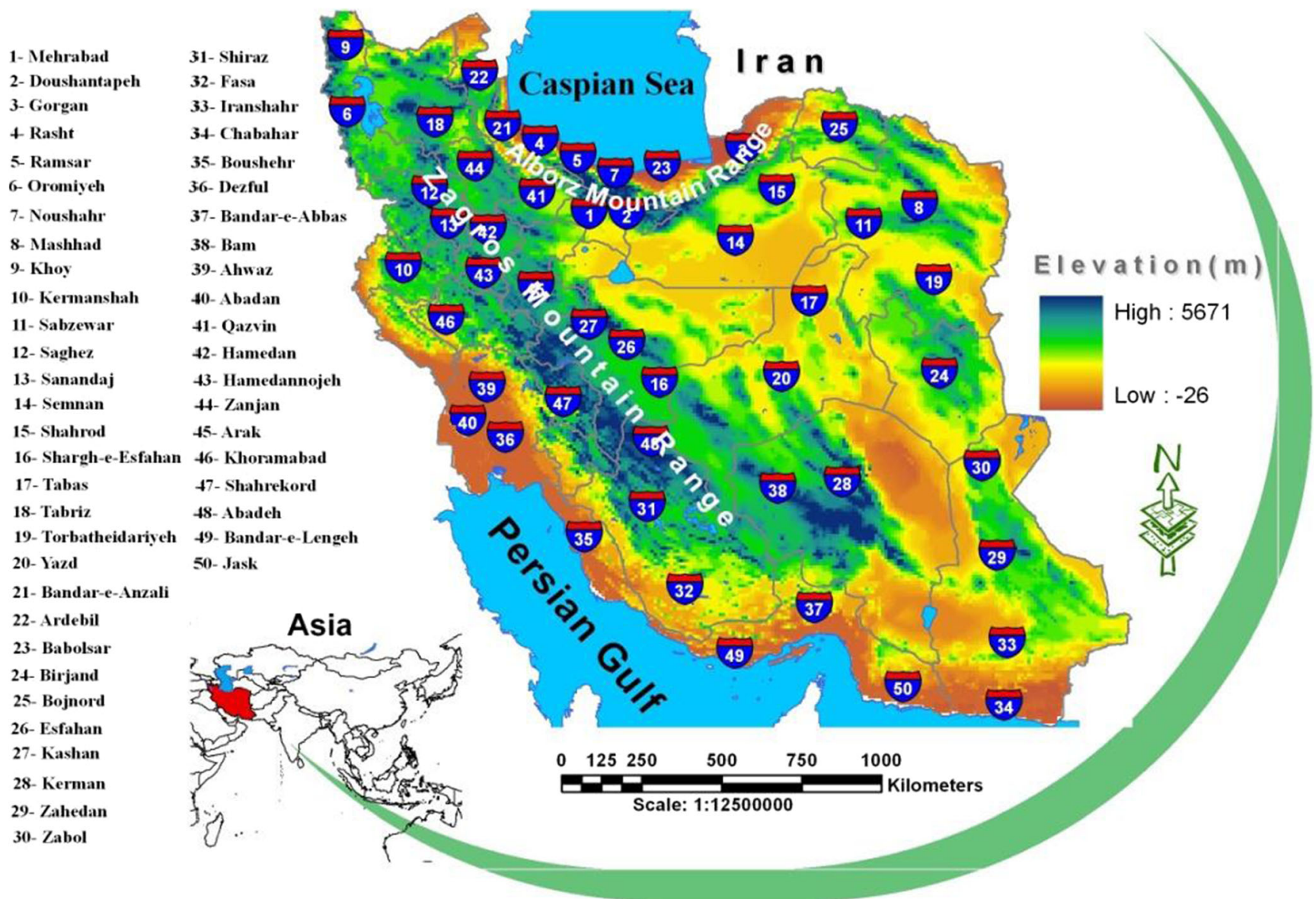

Fig. 1 List and locations of the 50 weather stations utilized in this study and the topography of the country

Warm (WSDI) and cold (CSDI) spell duration indicators consider long-lasting events of warm and cold days based on two different percentiles. Monthly extreme temperature indices, the highest and lowest daily maximum and minimum temperatures for a given month (TXx, TXn, $\mathrm{TNx}$, and $\mathrm{TNn}$ ), and diurnal temperature range (DTR) are identified with maximum or minimum monthly records at individual weather stations. Fixed threshold indices include summer days (SU), ice days (ID), tropical nights (TR), frost days (FD), and growing season lengths (GSL). Stronger/weaker extremes are defined as $5{ }^{\circ} \mathrm{C}$ above or below the fixed thresholds. For precipitation indices, which are based on relative thresholds, upper fifth (R95p) and first (R99p) percentiles are used to calculate the accumulation of extreme wet day precipitation values. Single-day precipitation totals are considered (RX1day), and the consecutive day accumulation at individual weather stations is used to define monthly maximum 5day precipitation values (RX5day). Successive dry (CDD) and wet (CWD) days are used to examine durational characteristics of extreme precipitation events. Annual average characteristics of precipitation events are represented in annual total wet-day precipitation (PRCPTOT) and simple daily intensity index (SDII). Extreme precipitation events exceeding absolute thresholds of precipitation are characterized by the number of days with precipitation exceeding $10 \mathrm{~mm}(\mathrm{R} 10 \mathrm{~mm}), 20 \mathrm{~mm}(\mathrm{R} 20 \mathrm{~mm})$, and $35 \mathrm{~mm}$ (R35mm).

The estimated linear trends across the 50 weather stations are regionally averaged to examine the nationwide tendencies in Iran. Regional variations across Iran are visualized using spatial trend maps, where individual observation stations are interpolated with Inverse Distance Weighting (IDW). Additionally, time series of interannual anomalies of seasonal/ annual averages and maximum/minimum temperatures are calculated at individual weather stations. Spatial distribution maps considering the sign, as well as the changes and magnitude of each index, are presented. Seasonal relationships between the changes in climate means and extreme events across 50 weather stations are analyzed via scatter plots and linear regression analyses. Moreover, trends and annual time series mean values for annual series of percentile temperature indices for cold and warm day/nights, in addition to the precipitation indices (simple daily intensity index and heavy precipitation, very wet, and consecutive dry day indices), were drawn during the examined period. 
Table 1 Geographical characteristics of the selected weather sites and defined regions across Iran during the period 1975-2010

\begin{tabular}{|c|c|c|c|c|c|}
\hline No. & Regions & Station name & Latitude $(\mathrm{N})$ & Longitude (E) & Elevation (m) \\
\hline 1 & \multirow[t]{10}{*}{ Northwest } & Khoy & $38^{\circ} 33^{\prime}$ & $44^{\circ} 58^{\prime}$ & 1103 \\
\hline 2 & & Oroomieh & $37^{\circ} 32^{\prime}$ & $45^{\circ} 05^{\prime}$ & 1315.9 \\
\hline 3 & & Tabriz & $38^{\circ} 05^{\prime}$ & $46^{\circ} 17^{\prime}$ & 1361 \\
\hline 4 & & Ardebil & $38^{\circ} 15^{\prime}$ & $48^{\circ} 17^{\prime}$ & 1332 \\
\hline 5 & & Zanjan & $36^{\circ} 41^{\prime}$ & $48^{\circ} 29^{\prime}$ & 1663 \\
\hline 6 & & Saghez & $36^{\circ} 15^{\prime}$ & $46^{\circ} 16^{\prime}$ & 1522.8 \\
\hline 7 & & Qazvin & $36^{\circ} 15^{\prime}$ & $50^{\circ} 03^{\prime}$ & 1279.2 \\
\hline 8 & & Hamedan Forodgah & $34^{\circ} 52^{\prime}$ & $48^{\circ} 32^{\prime}$ & 1741.5 \\
\hline 9 & & Hamedan Noujeh & $35^{\circ} 12^{\prime}$ & $48^{\circ} 43^{\prime}$ & 1679.7 \\
\hline 10 & & Sanandaj & $35^{\circ} 20^{\prime}$ & $47^{\circ} 00^{\prime}$ & 1373.4 \\
\hline 11 & \multirow[t]{6}{*}{ North } & Gorgan & $36^{\circ} 51^{\prime}$ & $54^{\circ} 16^{\prime}$ & 13.3 \\
\hline 12 & & Noushahr & $36^{\circ} 39^{\prime}$ & $51^{\circ} 30^{\prime}$ & -20.9 \\
\hline 13 & & Babolsar & $36^{\circ} 43^{\prime}$ & $52^{\circ} 39^{\prime \prime}$ & -21 \\
\hline 14 & & Ramsar & $36^{\circ} 54^{\prime}$ & $50^{\circ} 40^{\prime}$ & -20 \\
\hline 15 & & Rasht & $37^{\circ} 12^{\prime}$ & $49^{\circ} 39^{\prime}$ & 3607 \\
\hline 16 & & Bandar-e-Anzali & $37^{\circ} 28^{\prime}$ & $49^{\circ} 28^{\prime}$ & -26.2 \\
\hline 17 & \multirow[t]{3}{*}{ Northeast } & Mashhad & $36^{\circ} 16^{\prime}$ & $59^{\circ} 38^{\prime}$ & 999.2 \\
\hline 18 & & Bojnourd & $37^{\circ} 28^{\prime}$ & $57^{\circ} 19^{\prime}$ & 1091 \\
\hline 19 & & Sabzewar & $36^{\circ} 12^{\prime}$ & $57^{\circ} 43^{\prime}$ & 977.6 \\
\hline 20 & \multirow[t]{4}{*}{ West } & Kermanshah & $34^{\circ} 21^{\prime}$ & $47^{\circ} 09^{\prime}$ & 1318.6 \\
\hline 21 & & Khoramabad & $23^{\circ} 26^{\prime}$ & $48^{\circ} 17^{\prime}$ & 1147.8 \\
\hline 22 & & Arak & $34^{\circ} 06^{\prime}$ & $49^{\circ} 46^{\prime}$ & 1708 \\
\hline 23 & & Shahrekord & $32^{\circ} 17^{\prime}$ & $50^{\circ} 51^{\prime}$ & 2048.9 \\
\hline 24 & \multirow[t]{9}{*}{ Central } & Tehran & $35^{\circ} 41^{\prime}$ & $51^{\circ} 19^{\prime}$ & 1190.8 \\
\hline 25 & & Doshantapeh & $35^{\circ} 42^{\prime}$ & $51^{\circ} 20^{\prime}$ & 1209.2 \\
\hline 26 & & Semnan & $35^{\circ} 35^{\prime}$ & $53^{\circ} 33^{\prime}$ & 1130.8 \\
\hline 27 & & Tabas & $33^{\circ} 36^{\prime}$ & $56^{\circ} 55^{\prime}$ & 711 \\
\hline 28 & & Yazd & $31^{\circ} 54^{\prime}$ & $54^{\circ} 17^{\prime}$ & 1237.2 \\
\hline 29 & & Esfahan & $32^{\circ} 37^{\prime}$ & $51^{\circ} 40^{\prime}$ & 1550.4 \\
\hline 30 & & Shargh-e-Esfahan & $32^{\circ} 40^{\prime}$ & $51^{\circ} 52^{\prime}$ & 1543 \\
\hline 31 & & Kashan & $33^{\circ} 59^{\prime}$ & $51^{\circ} 27^{\prime}$ & 982.3 \\
\hline 32 & & Shahroud & $36^{\circ} 25^{\prime}$ & $54^{\circ} 57^{\prime}$ & 1345.3 \\
\hline 33 & \multirow[t]{3}{*}{ East } & Birjand & $32^{\circ} 52^{\prime}$ & $59^{\circ} 12^{\prime}$ & 1491 \\
\hline 34 & & Torbatheidarieh & $35^{\circ} 16^{\prime}$ & $59^{\circ} 13^{\prime}$ & 1450.8 \\
\hline 35 & & Zabol & $31^{\circ} 02^{\prime}$ & $61^{\circ} 29^{\prime}$ & 489.2 \\
\hline 36 & \multirow[t]{6}{*}{ Southwest } & Ahwaz & $31^{\circ} 20^{\prime}$ & $48^{\circ} 40^{\prime}$ & 22.5 \\
\hline 37 & & Abadan & $30^{\circ} 22^{\prime}$ & $48^{\circ} 15^{\prime}$ & 606 \\
\hline 38 & & Abadeh & $31^{\circ} 11^{\prime}$ & $52^{\circ} 40^{\prime}$ & 2030 \\
\hline 39 & & Dezful & $32^{\circ} 24^{\prime}$ & $48^{\circ} 23^{\prime}$ & 143 \\
\hline 40 & & Bushehr & $28^{\circ} 59^{\prime}$ & $50^{\circ} 50^{\prime}$ & 19.6 \\
\hline 41 & & Shiraz & $29^{\circ} 32^{\prime}$ & $52^{\circ} 36^{\prime}$ & 1484 \\
\hline 42 & \multirow[t]{4}{*}{ South } & Bandar-e-Lengeh & $26^{\circ} 32^{\prime}$ & $54^{\circ} 50^{\prime}$ & 22.7 \\
\hline 43 & & Fasa & $28^{\circ} 58^{\prime}$ & $53^{\circ} 41^{\prime}$ & 1288.3 \\
\hline 44 & & Bandarabas & $27^{\circ} 13^{\prime}$ & $56^{\circ} 22^{\prime}$ & 9.8 \\
\hline 45 & & Jask & $25^{\circ} 38^{\prime}$ & $57^{\circ} 46^{\prime}$ & 5.2 \\
\hline 46 & \multirow[t]{5}{*}{ Southeast } & Chabahar & $25^{\circ} 17^{\prime}$ & $60^{\circ} 37^{\prime}$ & 8 \\
\hline 47 & & Iranshahr & $27^{\circ} 12^{\prime}$ & $60^{\circ} 42^{\prime}$ & 591.1 \\
\hline 48 & & Zahedan & $29^{\circ} 28^{\prime}$ & $60^{\circ} 53^{\prime}$ & 1370 \\
\hline 49 & & Kerman & $30^{\circ} 15^{\prime}$ & $56^{\circ} 58^{\prime}$ & 1753.8 \\
\hline 50 & & Bam & $29^{\circ} 06^{\prime}$ & $58^{\circ} 21^{\prime}$ & 1066.9 \\
\hline
\end{tabular}


Table 2 The 27 extreme temperature and precipitation indices (Karl et al. 1999; Peterson 2005)

\begin{tabular}{|c|c|c|c|}
\hline Index & Descriptive name & Definition & Units \\
\hline & & Hot extreme temperature indices & \\
\hline GSL & Growing season length & $\begin{array}{l}\text { Annual count between first span of at least } 6 \text { days with TG }>5^{\circ} \mathrm{C} \\
\text { after winter and first span after summer of } 6 \text { days with } \mathrm{TG}<5^{\circ} \mathrm{C}\end{array}$ & Days \\
\hline SU & Summer days & Annual count of summer days when daily maximum temperature (TX) $>27{ }^{\circ} \mathrm{C}$ & Days \\
\hline TR & Tropical nights & Annual count when $\mathrm{TN}>5^{\circ} \mathrm{C}$ & Days \\
\hline TXx & Max Tmax & $\begin{array}{l}\text { Monthly maximum value of daily maximum temperature. } \mathrm{Tx}_{k j} \text { can be } \\
\text { defined as the daily maximum temperatures in month } k \text {, period } j\end{array}$ & ${ }^{\circ} \mathrm{C}$ \\
\hline $\mathrm{TNx}$ & Max Tmin & Monthly highest TN & ${ }^{\circ} \mathrm{C}$ \\
\hline TN90p & Warm nights & $\begin{array}{l}\text { Percentage of days when monthly value of daily minimum temperature } \\
(\mathrm{TN})>90 \text { th percentile during } 1975-2010\end{array}$ & $\%$ \\
\hline TX90p & Warm days & $\begin{array}{l}\text { Percentage of days when monthly value of daily maximum temperature } \\
\text { (TX) > 90th percentile during 1975-2010 }\end{array}$ & $\%$ \\
\hline WSDI & Warm spell duration indicator & $\begin{array}{l}\text { Annual count of days with at least } 6 \text { consecutive days when TX }>90 \text { th } \\
\text { percentile during } 1975-2010 \\
\text { Cold extreme temperature indices }\end{array}$ & Days \\
\hline CSDI & Cold spell duration indicator & $\begin{array}{l}\text { Annual count of days with at least } 6 \text { consecutive days when TN }>10 \text { th } \\
\text { percentile during 1975-2010 }\end{array}$ & Days \\
\hline DTR & Diurnal temperature range & Monthly mean temperature difference between TX and TN & ${ }^{\circ} \mathrm{C}$ \\
\hline FD & Frost days & Annual count of frost days when daily minimum temperature $\mathrm{TN}<0{ }^{\circ} \mathrm{C}$ & Days \\
\hline ID & Ice days & Annual count of icing days when $\mathrm{TX}<2{ }^{\circ} \mathrm{C}$ & Days \\
\hline TXn & Min Tmax & Monthly lowest TX & ${ }^{\circ} \mathrm{C}$ \\
\hline $\mathrm{TNn}$ & Min Tmin & $\begin{array}{l}\text { Monthly minimum value of daily minimum temperature. } \mathrm{Tx}_{k j} \text { can be } \\
\text { defined as the daily minimum temperatures in month } k \text {, period } j\end{array}$ & ${ }^{\circ} \mathrm{C}$ \\
\hline TN10p & Cold nights & $\begin{array}{l}\text { Percentage of days when monthly value of daily minimum temperature } \\
\text { (TN) < 10th percentile during } 1975-2010\end{array}$ & $\%$ \\
\hline TX10p & Cold days & $\begin{array}{l}\text { Percentage of days when monthly value of daily maximum temperature } \\
\quad(\mathrm{TX})<10 \text { th percentile during } 1975-2010 \\
\text { Extreme precipitation indices }\end{array}$ & $\%$ \\
\hline CDD & Consecutive dry days & Maximum number of consecutive dry days & Days \\
\hline CWD & Consecutive wet days & $\begin{array}{l}\text { Count the largest number of consecutive days where } \mathrm{RR}_{i j} \geq 1 \mathrm{~mm} \text {, } \\
\text { where } \mathrm{RR}_{i j} \text { is the daily precipitation amount on day } i \text { in period } j\end{array}$ & Days \\
\hline PRCPTOT & Wet day precipitation & Annual total precipitation from wet days & $\mathrm{mm}$ \\
\hline $\mathrm{R} 10 \mathrm{~mm}$ & Heavy precipitation days & Annual count of days when $R R \geq 10 \mathrm{~mm}$ & Days \\
\hline $\mathrm{R} 20 \mathrm{~mm}$ & Very heavy precipitation days & Annual count of days when $R R \geq 20 \mathrm{~mm}$ & Days \\
\hline $\mathrm{R} 35 \mathrm{~mm}$ & $\begin{array}{l}\text { Number of days have precipitation } \\
\text { above } 35 \mathrm{~mm}\end{array}$ & Annual count of days when $R R \geq 35 \mathrm{~mm}$ & Days \\
\hline R95p & Very wet days & $\begin{array}{l}\text { Count the largest number of consecutive wet days when the amount of } \\
\text { rainfall falling above the 95th percentiles during 1975-2010 }\end{array}$ & $\mathrm{mm}$ \\
\hline $\mathrm{R} 99 \mathrm{p}$ & Extremely wet days & $\begin{array}{l}\text { Count the largest number of consecutive wet days when the amount of } \\
\text { rainfall falling above the 99th percentiles during } 1975-2010\end{array}$ & $\mathrm{~mm}$ \\
\hline RX1day & Max 1-day precipitation amount & The maximum 1-day precipitation each month & $\mathrm{mm}$ \\
\hline RX5day & Max 5-day precipitation amount & The maximum 5-day precipitation each month & $\mathrm{mm}$ \\
\hline SDII & Simple daily intensity index & Average precipitation on wet days & $\mathrm{mm} / \mathrm{day}$ \\
\hline
\end{tabular}

\section{Results}

\subsection{Annual and seasonal changes in temperature means and extreme events}

\subsubsection{Trends in temperature means and frequency of extreme temperature events}

Regional changes in the annual averages of maximum and minimum temperatures, winter and summer periods during
1975-2010 over Iran are shown in Fig. 2. The annual maximum and minimum average temperatures across the country have increased by 0.031 and $0.059{ }^{\circ} \mathrm{C} /$ decade, respectively (Fig. 2). The rate of annual minimum temperature increase is nearly double the annual maximum temperatures over the country. The northeastern regions have the largest difference between the amounts of annual minimum/maximum temperature rise at $0.1{ }^{\circ} \mathrm{C} /$ decade compared to the small differentiation in the northwestern $\left(0.001{ }^{\circ} \mathrm{C} /\right.$ decade $)$ and eastern $\left(0.005{ }^{\circ} \mathrm{C} /\right.$ decade $)$ regions. Average winter max and min 
Fig. 2 Changes in mean, a maximum, and $\mathbf{b}$ minimum temperatures over Iran for annual (green), winter (blue), and summer (red) periods during 1975-2010
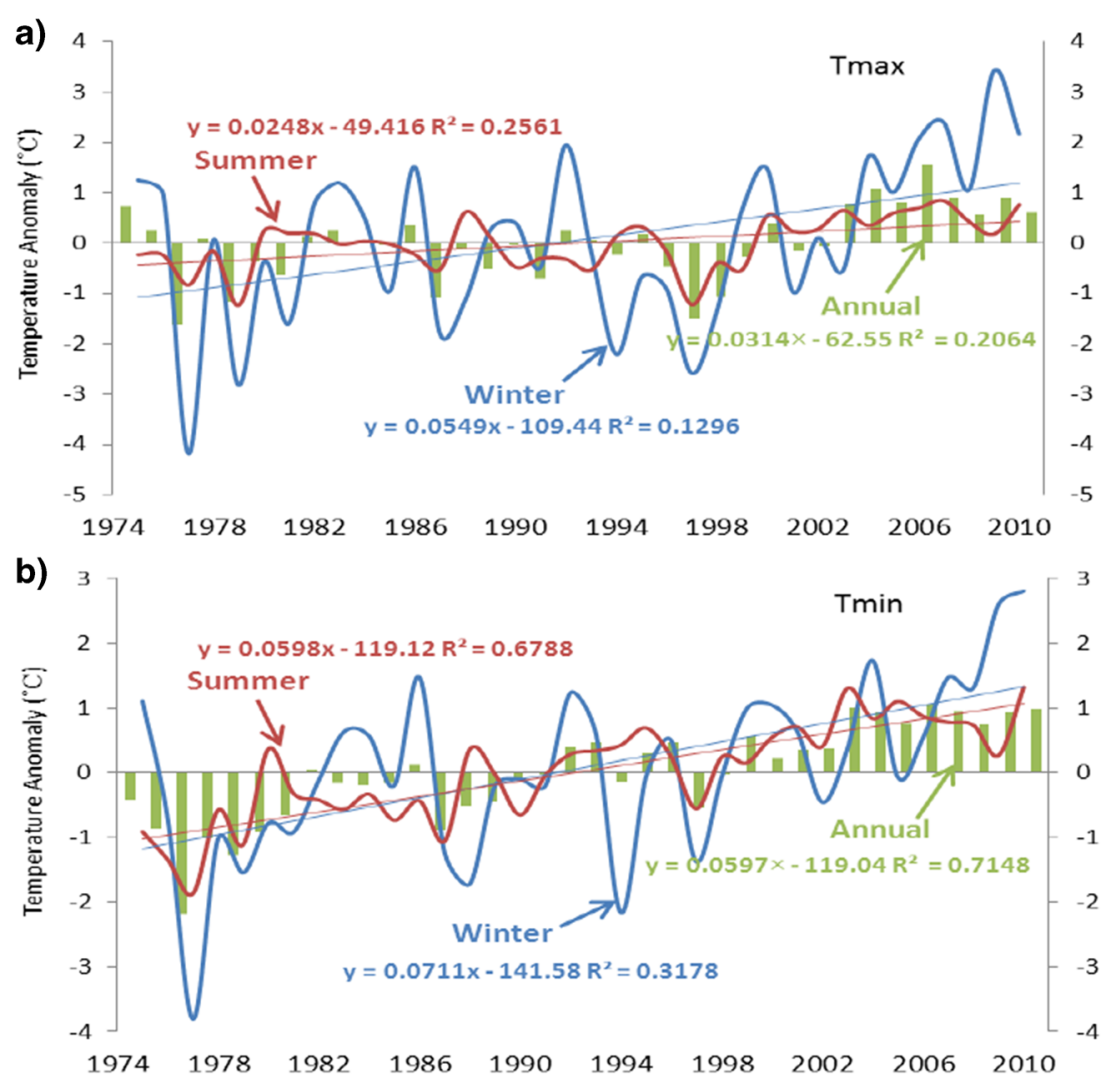

temperature changes are greater than those in summer, with growth rates of 0.05 and $0.07{ }^{\circ} \mathrm{C} /$ decade in winter, respectively, and 0.02 and $0.06{ }^{\circ} \mathrm{C} /$ decade in summer, respectively.

Nocturnal influences have a larger contribution than daily changes on mean temperature, as indicated by a larger minima temperature increase compared to the maxima; however, the sign and magnitude of seasonal temperature variations is spatially dependent (Table 3). Sites located in the west and central regions of Iran exhibit greater rates of intensification in winter maximum temperature $\left(0.08-0.06{ }^{\circ} \mathrm{C} / \mathrm{decade}\right)$ compared to the minimum $\left(0.02-0.01{ }^{\circ} \mathrm{C} /\right.$ decade), in opposition of the country-wide trends. Differences between winter minimum and maximum temperature rates of alteration are greatest in the southwest at 0.06 and $0.14{ }^{\circ} \mathrm{C} /$ decade during the summer. In contrast, the eastern regions have the smallest difference in summer rates at $0.002{ }^{\circ} \mathrm{C} /$ decade. Trends in the northwest and east regions are typically weaker for mean, maximum, and minimum temperatures. The time series of regional average change in extreme temperature indices of warm/cold days and warm/cold nights during 1975-2010 over Iran (Fig. 3) show a better fit from polynomial functions instead of linear regressions. The rate of change in extreme temperature events has, therefore, accelerated in the later part of the examined period. Despite the trend
Table 3 Linear trends $\left({ }^{\circ} \mathrm{C} /\right.$ decade) in winter, summer, and annual maximum/minimum temperatures in nine different geographic regions of Iran during 1975-2010 (discrimination of the regions is based on Table 1)

\begin{tabular}{|c|c|c|c|c|c|c|}
\hline \multirow{2}{*}{$\begin{array}{l}\text { Climate means } \\
\text { Regions }\end{array}$} & \multicolumn{4}{|c|}{ Trends of maximum temperature } & \multicolumn{2}{|c|}{ Trends of minimum temperature } \\
\hline & Winter & Summer & Annual & Winter & Summer & Annual \\
\hline Northwest & 0.095 & 0.030 & 0.054 & 0.079 & 0.039 & 0.055 \\
\hline North & 0.056 & -0.005 & 0.014 & 0.081 & 0.084 & 0.076 \\
\hline Northeast & 0.095 & 0.034 & 0.042 & 0.145 & 0.174 & 0.139 \\
\hline West & 0.079 & 0.061 & 0.067 & 0.015 & 0.075 & 0.059 \\
\hline Central & 0.061 & 0.059 & 0.051 & 0.005 & 0.004 & 0.002 \\
\hline East & 0.015 & 0.010 & 0.001 & 0.012 & 0.008 & 0.006 \\
\hline Southwest & 0.020 & 0.029 & 0.024 & 0.080 & 0.105 & 0.099 \\
\hline South & 0.003 & -0.014 & -0.002 & 0.020 & 0.017 & 0.021 \\
\hline Southeast & 0.051 & 0.014 & 0.023 & 0.062 & 0.043 & 0.053 \\
\hline
\end{tabular}


Fig. 3 Regional average changes in a warm days (TX90P)-cold days (TX10P), and $\mathbf{b}$ warm nights (TN90P)-cold nights (TN10P), averaged across Iran during 1975-2010
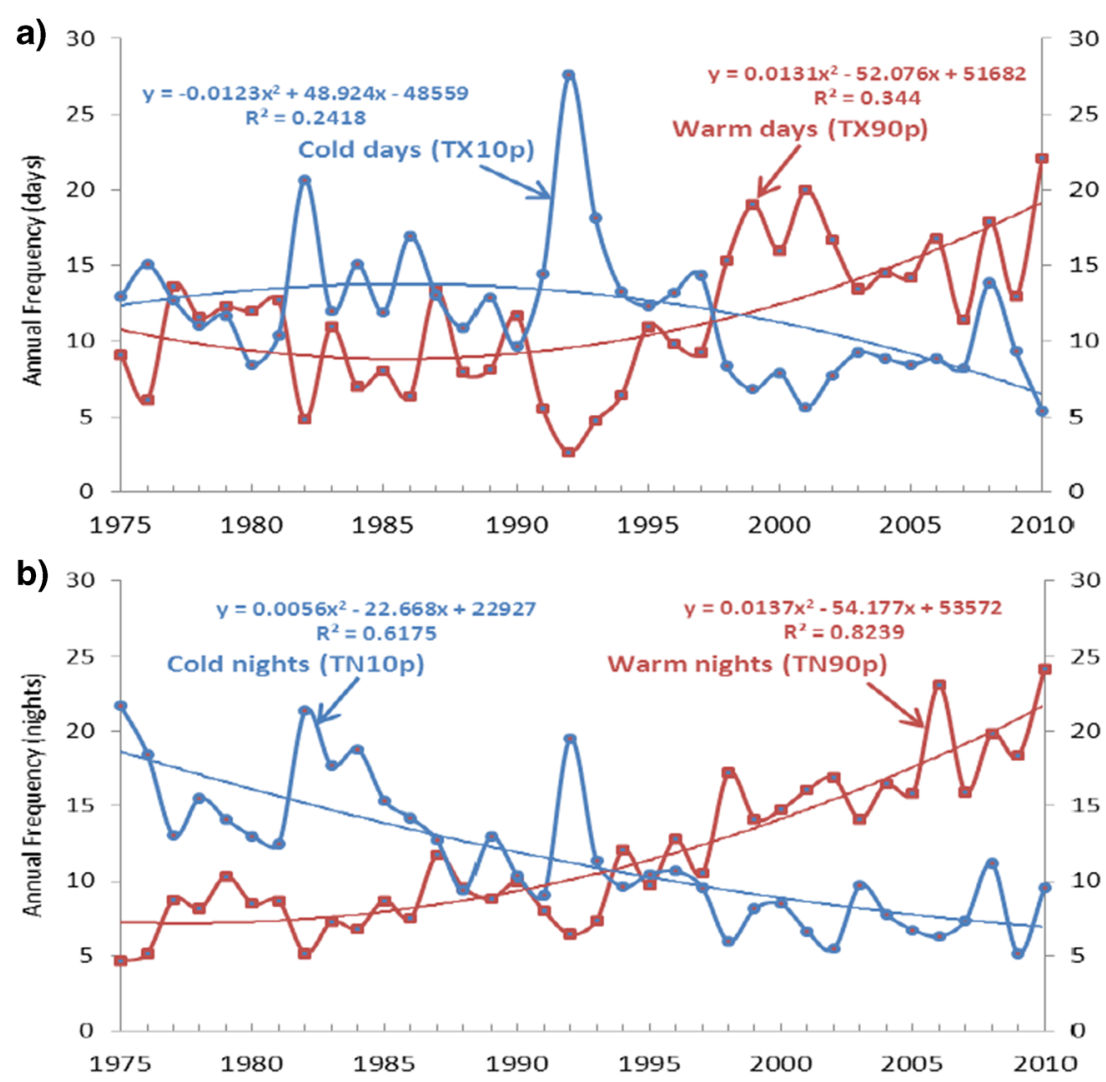

nonlinearity, the slopes of linear trends are utilized to ensure the comparability of trend magnitudes country-wide.

During the last 15 years (1995-2010), the annual frequency of warm days has substantially increased, 12 days/decade, whereas cold day incidence has decreased by 4 days/decade (Fig. 3a). Warm night annual frequency has dramatically expanded by 14 days/decade, while that of cold nights has dropped slightly by 3 days/decade (Fig. 3b). Rates of increase of the warm day and night annual frequencies have doubled in the last 15 years compared to the entire timeframe.

Through comprising the probability distribution functions (PDFs) of the annual percentage of cold nights and warm days in each of three 12-year subsets of the 36-year period, we found systematic shifts in the mean and variance of recent extreme temperature event frequency (Fig. 4). The mean of the PDF of cold nights has gradually decreased from $>20$ to $<15 \%$, with a reduced variance, between 1975-1986 and 1999-2010. Contrarily, the mean frequency of warm days has increased from 18 to $40 \%$, with an increased variance, between the two timeframes (Fig. 4).

\subsubsection{Changes in hot extreme temperature events (TXX, TNX, SU, TR, TX90p, TN90p, GSL, and WSDI)}

Extreme temperature indices listed in Table 2 are utilized to investigate climate extremes across Iran. Spatial distribution maps of trends in these indices at the individual stations provide more detailed information of how the magnitude of rates of change in extreme climate events varies from one
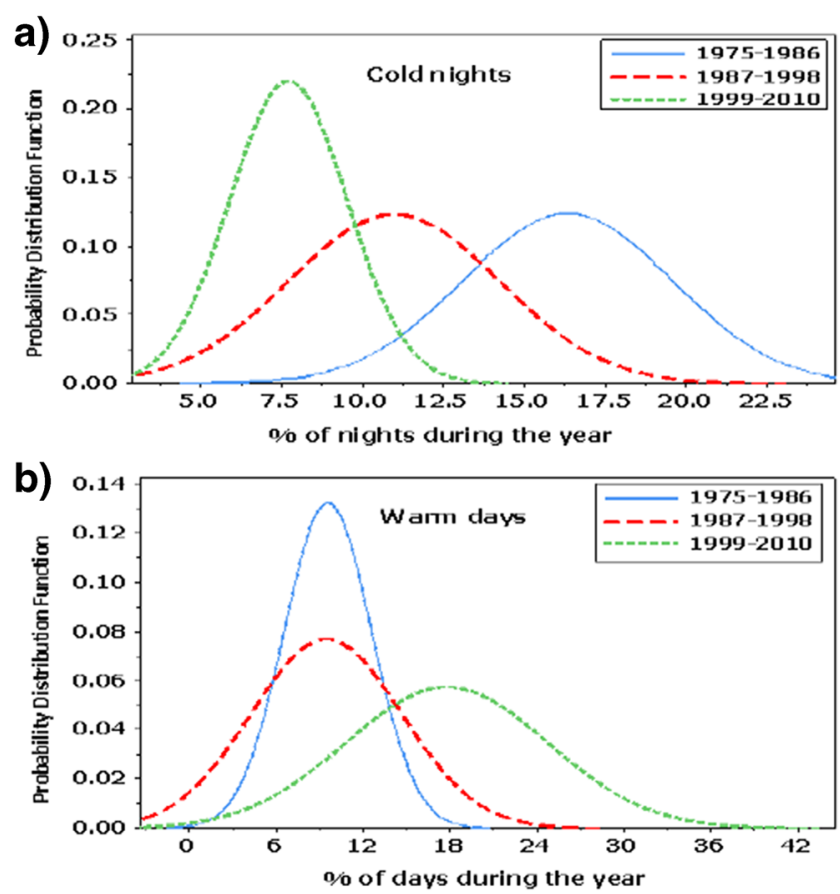

Fig. 4 Probability distribution function of annual frequency of a cold nights (TN10P) and b warm days (TX90P) for 50 weather stations across Iran for three 12-year periods: 1975-1986 (blue solid line), 1987-1998 (red dashed line), and 1999-2010 (green dotted line) 
weather station to another. Most stations exhibited a warming in temperature extremes, as shown in Figs. 5 and 6, and greater alteration in the nocturnal extreme temperature events versus daytime extreme incidences. Maximum temperature (TXx) trend increases occur at 29 stations, with 3 stations exhibiting significant trends (Esfahan, Yazd, and Zahedan stations). Thirteen of 50 stations have decreasing trends, $90 \%$ of which are situated in the Zagros mountain range. The Caspian Sea southern coast's stations remain predominantly unchanged (Fig. 5a).
Maximum of minimum temperature (TNx) shows considerably larger numbers of increasing and significant trends than TXx, with stations in the Alborz and Zagros mountain ranges and south/southeastern regions exhibiting significance. The strongest changes in TNx extremes are observed along the southern Caspian Sea coastline, while only Oroomieh, Saghez, and Esfahan remain unaltered (Fig. 5b). Summer days (SU) show similar positive trends compared to tropical nights (TR), with a slight difference geographically. Trend significance is found in 60-70\% of the stations in both indices
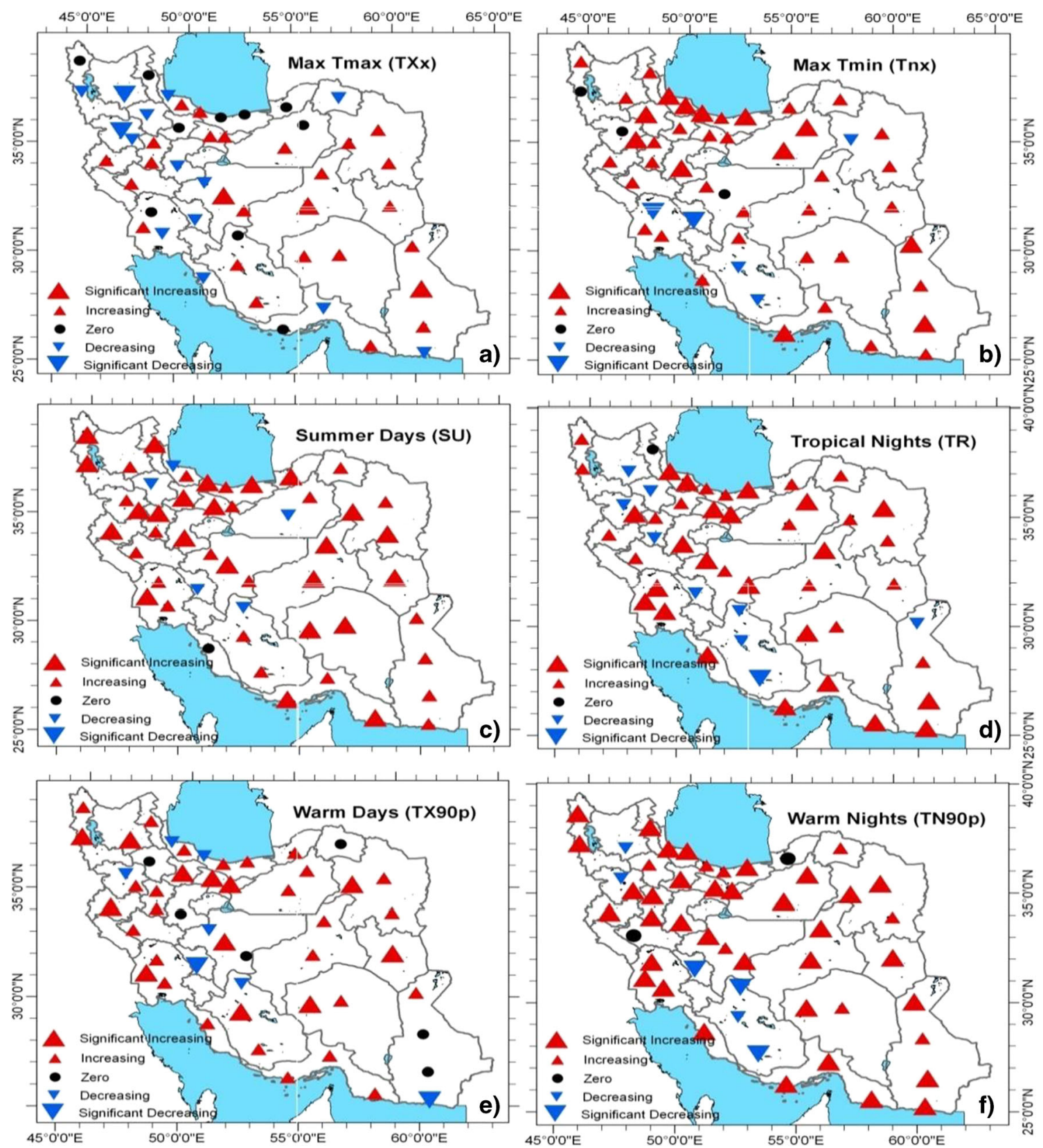

Fig. 5 Spatial distributions of hot extreme temperature events at 50 weather stations across Iran during 1975-2010: amax Tmax (TXx), bmax Tmin (TNx), c summer days (SU), d tropical nights (TR), e

warm days (TX90p), and f warm nights (TN90p). The direction of triangles indicates the signs of the changes, and the size of symbols represents the magnitude of the changes 


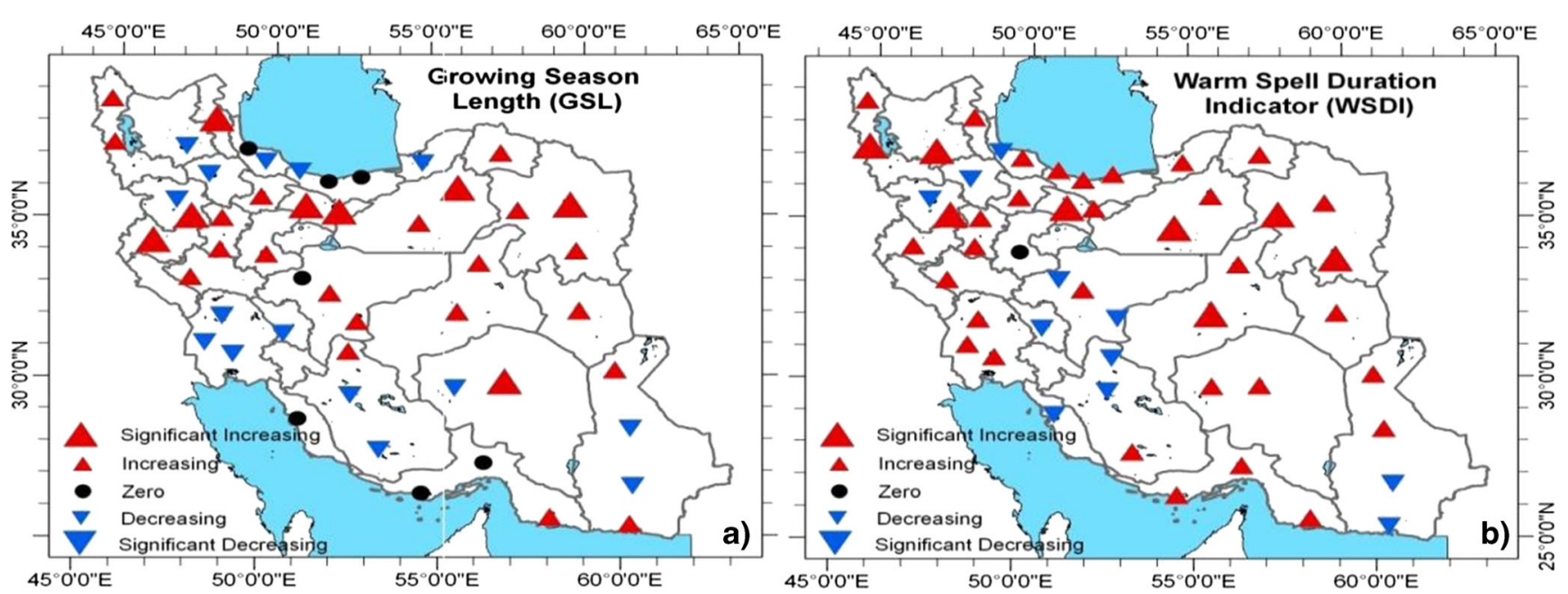

Fig. 6 Same as Fig. 5, but for a growing season length (GSL) and $\mathbf{b}$ warm spell duration indicator (WSDI)

(Fig. 5c, d); however, some stations over the Zagros mountain range have decreasing tendencies. Only Bushehr station in SU (Fig. 5c) and Ardebil station in TR (Fig. 5d) remained unchanged. Warm nights (TN90p) show greater positive trends than warm days (TX90p), with more than $90 \%$ of the stations significantly increasing in TN90p across Iran (Fig. 5f). Only seven stations show decreasing trends in warm days (Fig. 5e) and six for warm nights (Fig. 5f).

A majority of stations have an expanded growing season length (GSL), with 8 that are statistically significant; however, 15 in the northern and southern regions, which exhibit GSL reductions, and some coastal areas are neutral (Fig. 6a). A similar spatial pattern was found for the warm spell duration indicator (WSDI) with 8 stations significantly increasing, 11 decreasing (mainly in the Zagros Mountains), and 1 (Arak) with neutral trend (Fig. 6b).

\subsubsection{Changes in cold extreme temperature events (TNn, TXn, $F D, I D, T N 10 p$, TX10p, CSDI, and DRT)}

Cold extreme indices (Figs. 7 and 8), like hot indices, also show trends that are consistent with warming. The increasing trend in the minimum of minimum temperature (TNn) is identified at most stations, with 11 , which are statistically significant in the west and north areas of the country, and 12 in the south/southeast showing decreasing trends (Fig. 7a). The minimum of maximum temperature (TXn) is spatially similar to $\mathrm{TNn}$; however, there were more (16) decreasing trends in TXn (Fig. 7b). At 2 stations, TXn had significant increasing trend, while 11 significant increasing trends were found in TNn. In TXn and TNn, there are 11 and 8 neutral stations, respectively (Fig. 7a).

Frost/ice days (FD/ID) declined at a considerable number of the stations, but very few ID trends are significant (Fig. 7c, d). All the stations on the southern Caspian Sea coastline have fewer frost days, with statistical significance at Noushahr and
Ramsar. Stations located at the southern coast of Iran remained unchanged (Fig. 7c). Upwards of $95 \%$ of stations showed decreasing trends in ice days (ID) especially in the northwest, but unlike FD, stations located at the southern coast of Caspian indicated increasing or zero trends in ice days. In general, 18 stations are unaltered for the ID index, and 15 exhibit increases, with statistical significance at the Abadeh station (Fig. 7d).

In cold nights (TN10p), significant decreasing trends are observed at many stations, and only ten display increasing trends (Fig. 7e). More than $95 \%$ of the stations showed decreases in TX10p, and only Abadeh and Semnan expressed positive trends (Fig. 7f). On the whole, cold nights and days have significantly decreased across most of the country (Fig. 7e, f).

Several significantly decreasing trends in the cold spell duration indicator (CSDI) were identified across Iran, with most of the statistically significant stations in the Alborz and Zagros mountains (Fig. 8a). Only six of the stations showed positive trends (nonsignificant). The large number of negative diurnal temperature range (DTR) occurrences indicates that daily minimum temperature increases with higher magnitude than daily maximum temperatures at most stations. All of the observation points located at the southern coast of Caspian have negative tendencies, and stations along the southern Iranian coast show similar DTR results except at Bandarabas, which remains unchanged. Eleven points have positive trends, four of which are statistically significant (Fig. 8b).

Trends in the extreme temperature indices were compared to examine the consistency in the magnitude of change across individual sites (Fig. 9). The linear regression slope, fitted to the combined change rates of annual cold nights against annual warm nights, is 21.7 , while cold days versus warm days are 24.9 (Fig. 9a, b). According to these ratios, it is clear that the increased frequency of annual warm nights is greater than the decrease in cold nights across Iran (Figs. 5e and 7e), and frequency of annual warm 

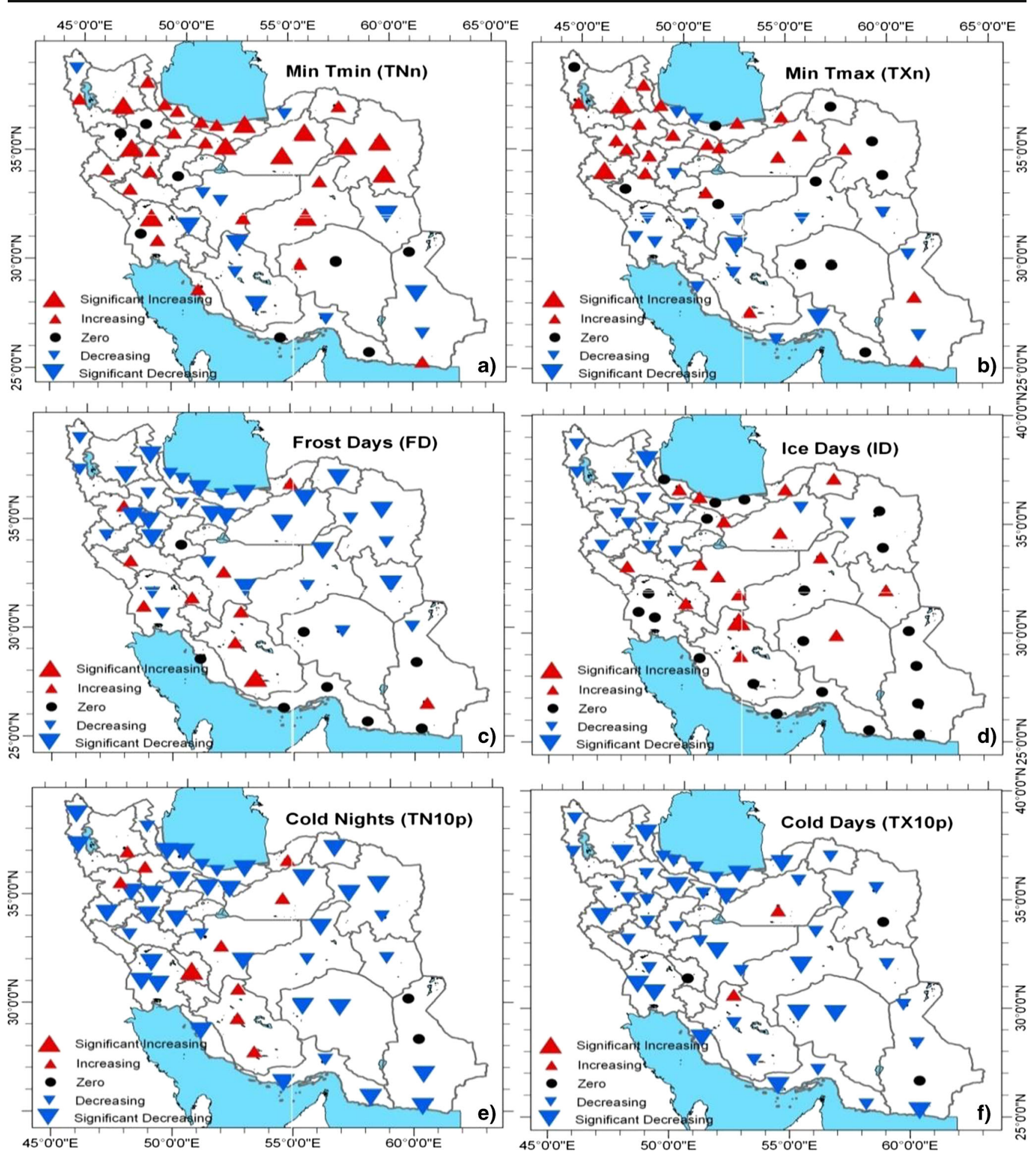

Fig. 7 Same as Fig. 5, but for cold extreme temperature events including: amin Tmin (TNn), bmin Tmax (TXn), c frost days (FD), d ice days (ID), e cold nights (TN10p), and $\mathbf{f}$ cold days (TX10p)

days increases faster than the rate of cold days decreases. Furthermore, the slope of the linear regression from the annual warm day alterations versus cold nights is 3.4 , while warm days against warm nights is 4.2 (Fig. 9c, d).

These slopes suggest that annual extreme temperature alteration is more apparent in nocturnal events than in daytime ones, reinforcing the earlier findings (Karl and Knight 1998; Moberg and Jones 2005; Brunetti et al. 2000; Choi et al. 2009; Alexander et al. 2006). The magnitude of change in warm and cold nights is typically more than double warm and cold days. Diurnal patterns in extreme temperature events in Iran have occurred asymmetrically over the 1975-2010 period, with stronger nighttime signals. 


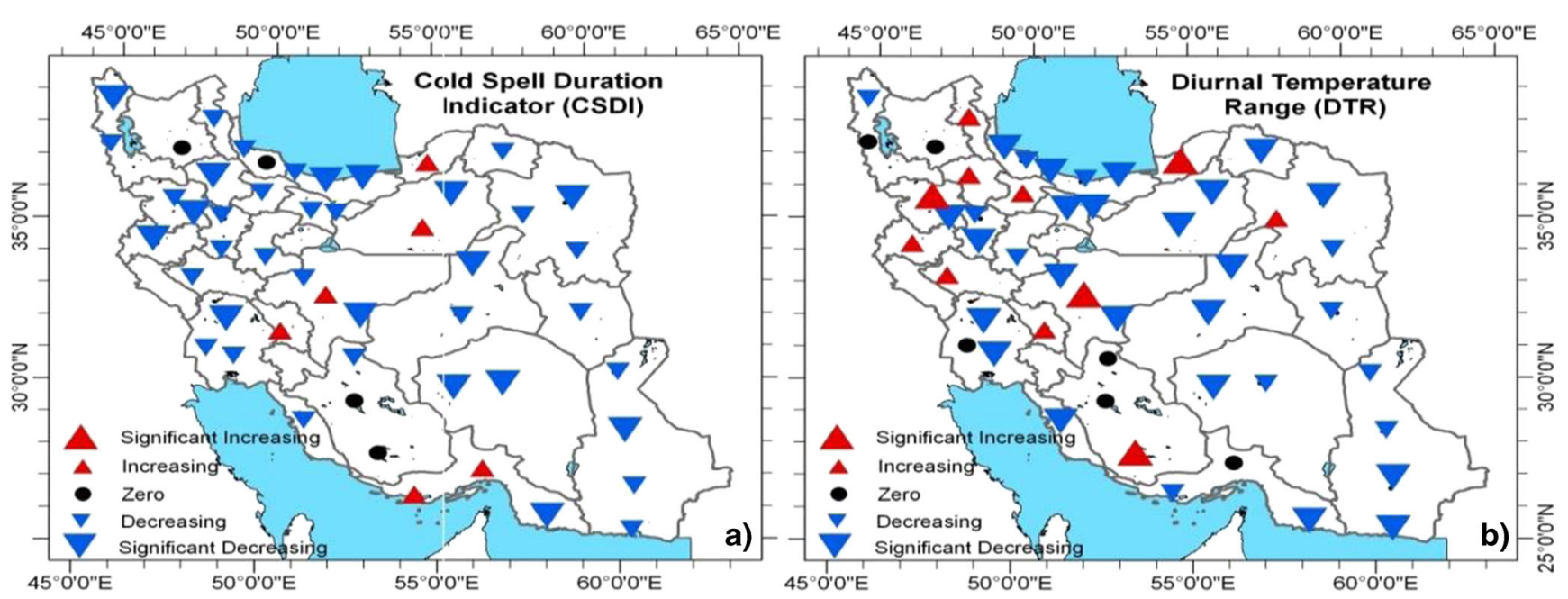

Fig. 8 Same as Fig. 5, but for cold extreme temperature events including: a cold spell duration indicator (CSDI) and b diurnal temperature range (DTR)

One of the main advantages of the ETCCDI and similar indices is the ability to combine regional information into a global product (Zhang et al. 2011). Spatial distribution and time series of estimated trends are shown in Fig. 10. According to the Figure, some indices exhibit significant increases in warm night frequency (Fig. 10b), but with less intensity than warm days (Fig. 10d), and a decrease in the number of cold nights (Fig. 10a) and cold days (Fig. 10c) across Iran for the entire study period, consistent
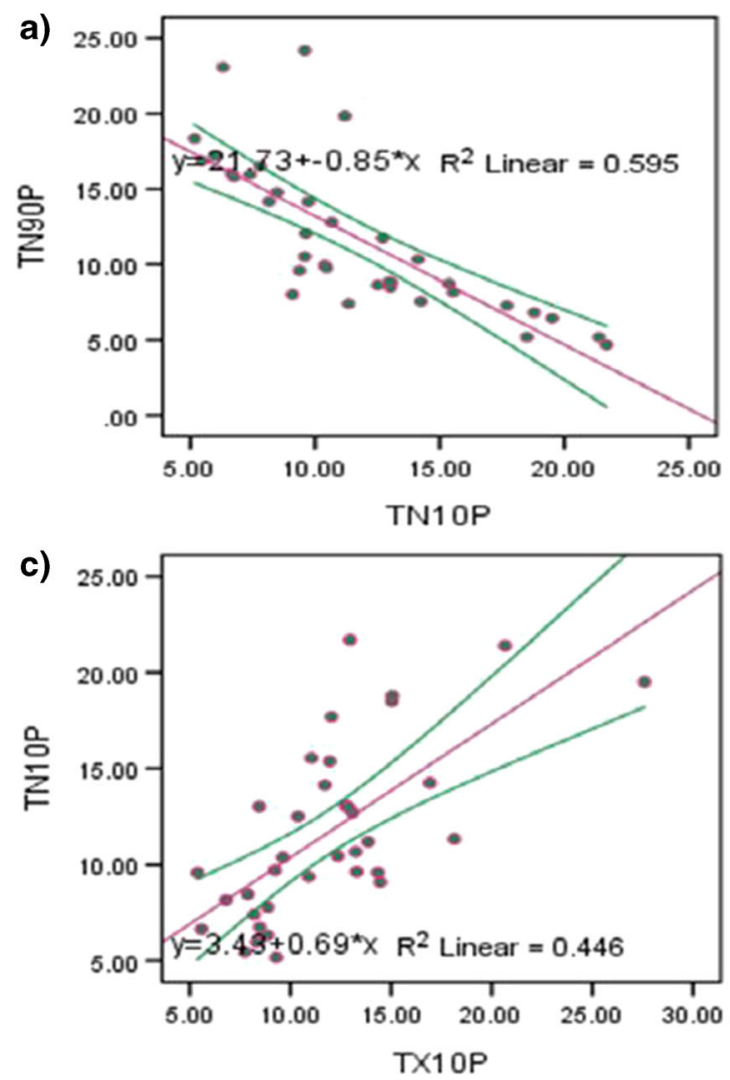

Fig. 9 a-d Comparisons of trends (days/decade) of extreme temperature events over 1975-2010 across Iran: cold nights (TN10P), cold days (TX10P), warm nights (TN90P), and warm days (TX90P). The purple with the previous results (Figs. 5e, f and 7e, f). These results illustrate the widespread, significant changes in temperature extremes associated with warming from 1975 to 2010 .

The cold night trend gradually decreases, while the opposite occurs for warm nights. Over $90 \%$ of the country shows a significant decrease in the annual occurrence of cold nights (Fig. 10a) and a significant increase in annual warm nights (Fig. 10b). Daily maximum temperature indices show similar
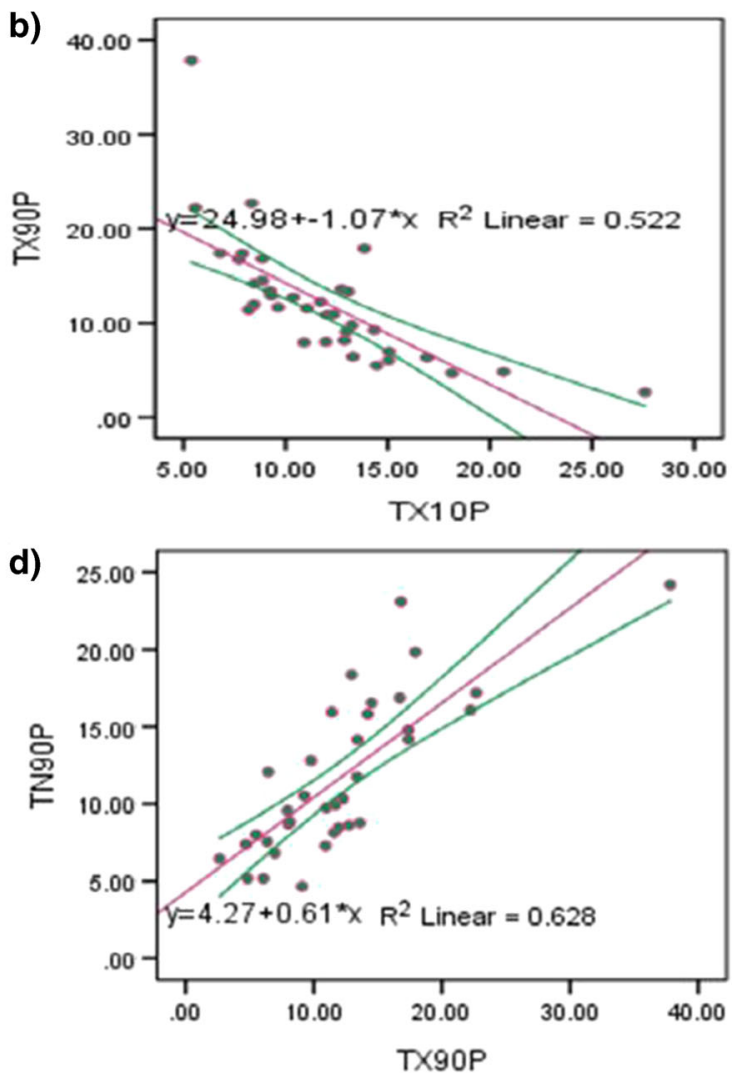

fit line indicates linear regression, and the green solid lines indicate mean confidence intervals at the $95 \%$ level 


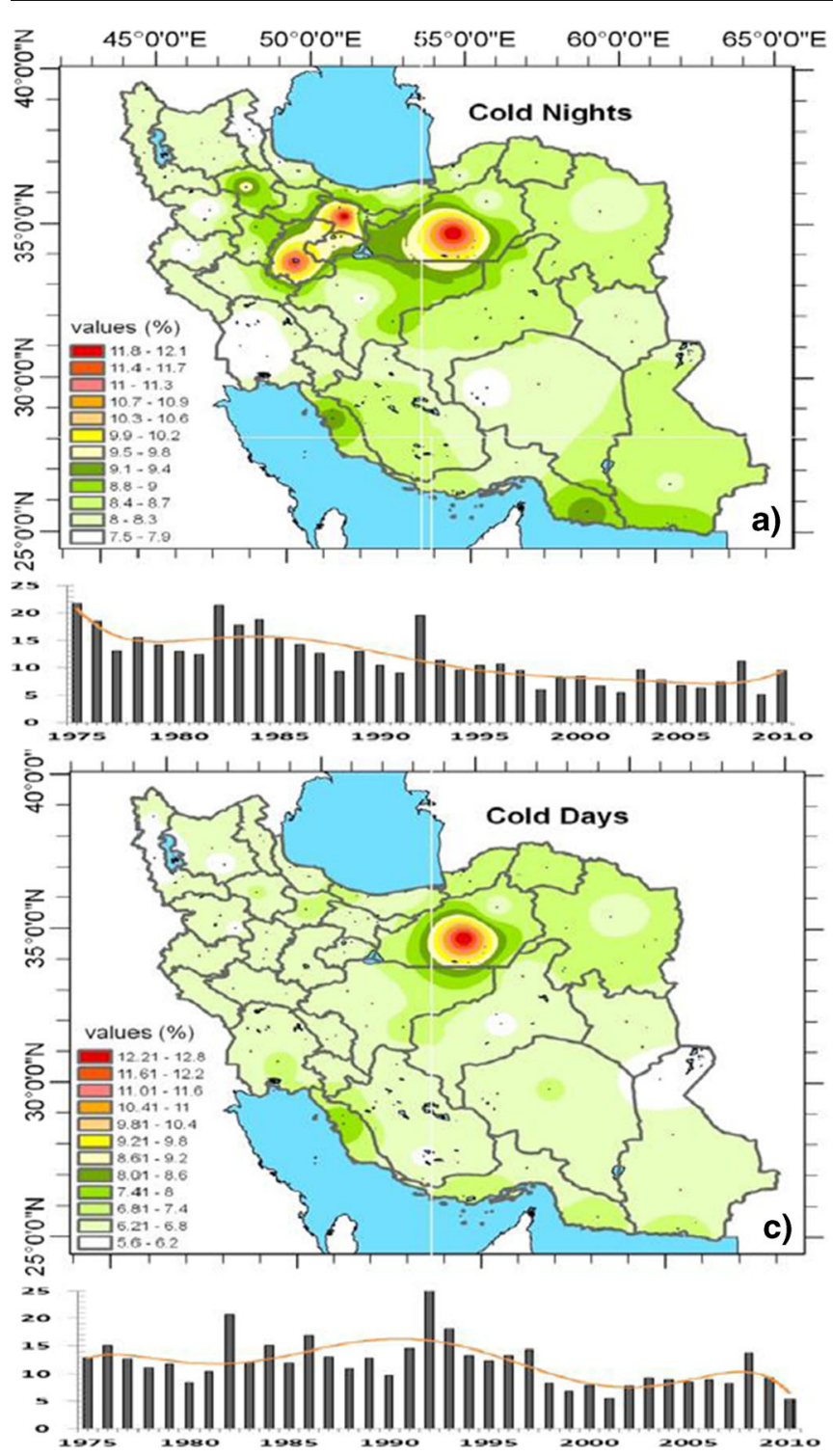

Fig. 10 Trends (days/decade, shown as maps) and annual time series mean values (plots) for annual series of percentile temperature indices for 1975-2010 for a cold nights (TN10p), b warm nights (TN90p), c

changes with smaller magnitudes (Fig. 10c, d), and fluctuations for the cold and warm day time series have descending and ascending tendencies at the end of the period, respectively (Fig. 10c, d).

\subsection{Annual and seasonal changes in precipitation totals and extremes}

\subsubsection{Annual and seasonal total precipitation}

Unlike mean or extremes of temperature, seasonal and annual precipitation does not show spatial continuity. Although significant interannual variation exists with significant
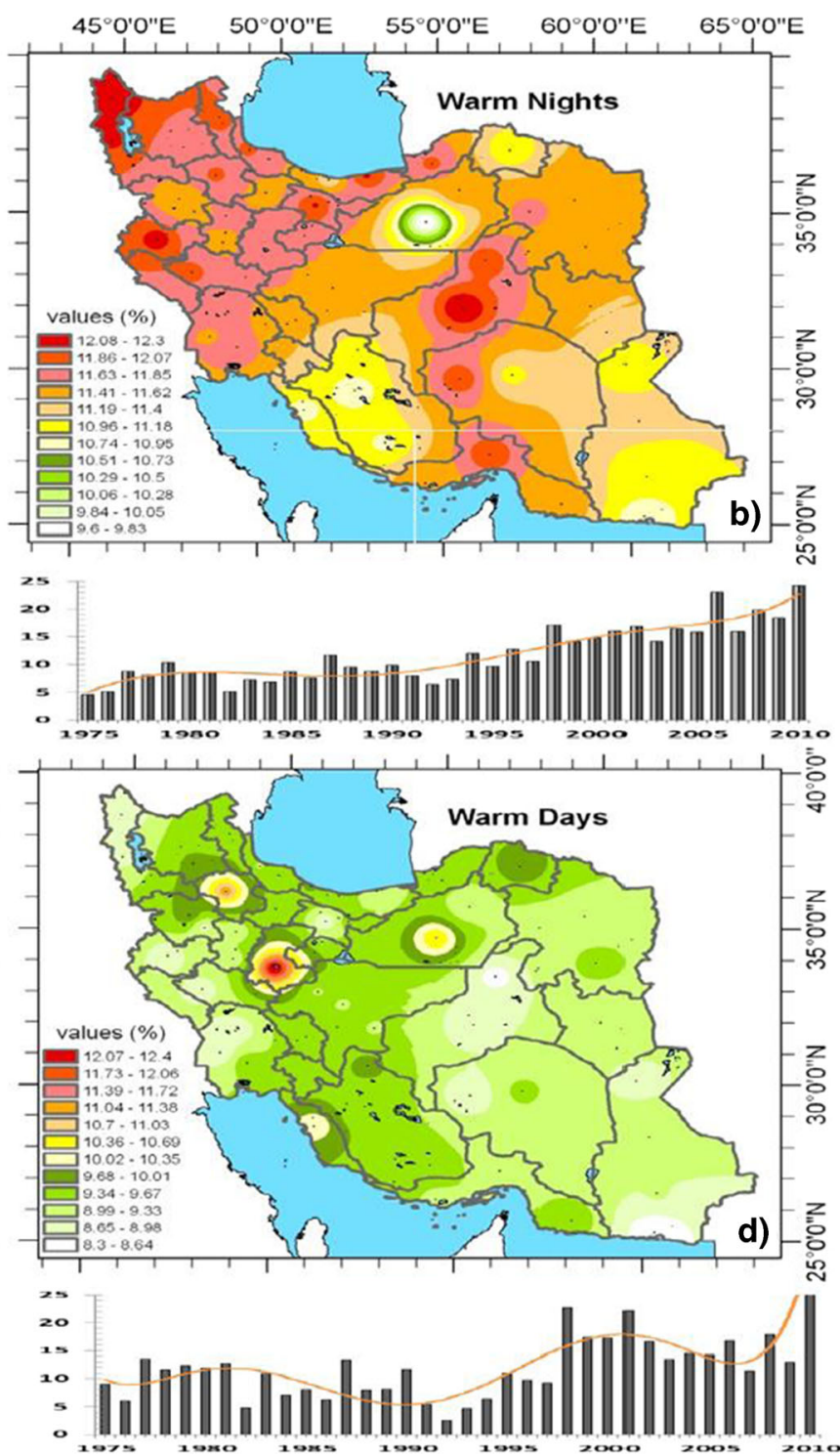

cold days (TX10p), and $\mathbf{d}$ warm days (TX90p). The orange curves on the plots are nonlinear trend estimates obtained by smoothing using a fifth-polynomial trend line

anomalies, there is negligible alteration in annual total precipitation $(-0.95 \mathrm{~mm} /$ decade) (Fig. 11).

The largest decreasing trend occurs in western regions of the country $(-3.34 \mathrm{~mm} /$ decade), and the central regions are the only locations with positive change $(0.11 \mathrm{~mm} /$ decade; Table 4). Total summertime precipitation has a slight increasing trend $(0.16 \mathrm{~mm} /$ decade $)$ because of positive anomalies since the late 1990s, while winter total precipitation expresses an insignificant negative change $(-0.75 \mathrm{~mm} /$ decade $)$. The greatest total summer precipitation increase can be found in the north $(1.81 \mathrm{~mm} /$ decade $)$. In winter, the greatest reduction occurred in northeastern regions, at $-5.51 \mathrm{~mm} /$ decade. Linear trends of annual and seasonal total precipitation in most regions of the country are not statistically significant (Table 4). 
Fig. 11 Same as Fig. 2, but for annual and seasonal total precipitation $(\mathrm{mm})$

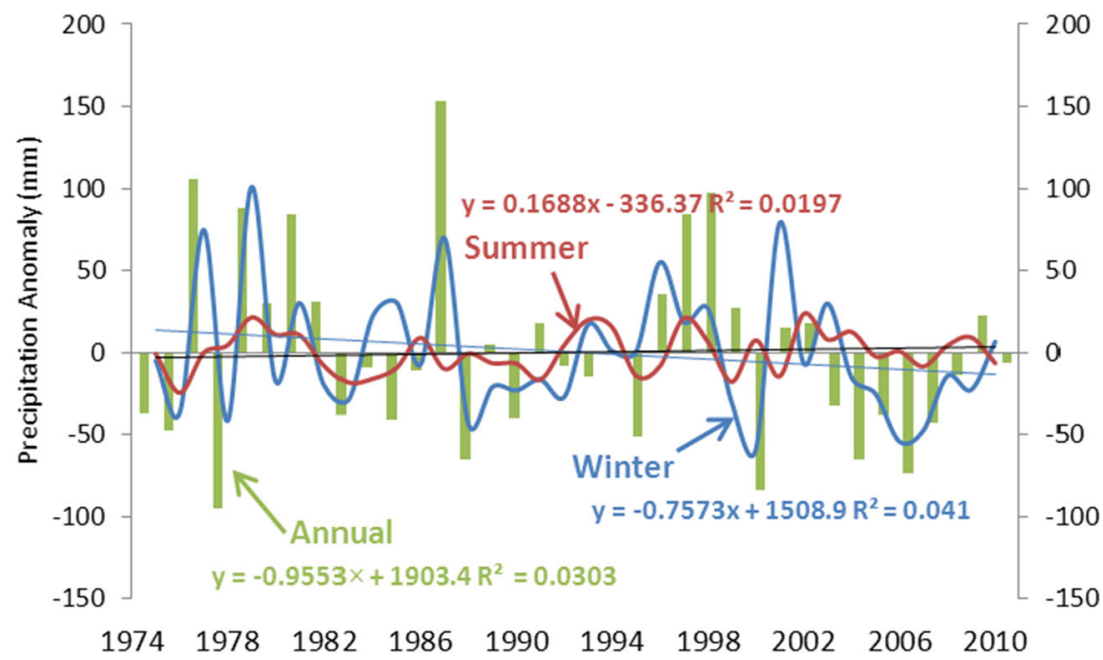

\subsubsection{Changes in extreme precipitation events}

Extreme precipitation indices have few significant changes, and in general, the amount, frequency, and intensity of precipitation in most regions of Iran decreased (Figs. 12 and 13).

More than $90 \%$ of the stations show a decreasing trend in heavy precipitation days (R10mm), five of which have statistically significant decreasing trends, located in the Caspian region, and Alborz/Zagros mountain ranges. Five stations have a positive trend in $\mathrm{R} 10 \mathrm{~mm}$, and the central and eastern areas are dominantly neutral (Fig. 12a). In contrast, the heavy precipitation days $(\mathrm{R} 20 \mathrm{~mm})$ have 12 positive trends, but overall have a majority of decreasing tendencies (Fig. 12b). Similar results are found for precipitation above $35 \mathrm{~mm}$ (R35mm) and very wet days (R95p).

Approximately $35 \%$ of the stations, mainly in mountainous areas, showed positive trends, although none were significant. The R35mm and R95p on the coastlines are decreasing (Fig. 12c, d), while in the remainder of the country, 27 stations have nonsignificant increases, $70 \%$ of which were located in the mountains. Fifteen stations have decreases in these indices, significant only at Tabas and Yazd in the central regions, and eastern parts of the coasts are neutrally effected (Fig. 12e). The increases found for consecutive dry days at 30 observation points were expected, given the water shortages over the past decade. While precipitation intensity predominantly increased, precipitation frequency has decreased, and this is detected via the R99p index increases (Fig. 12e, f). Both max 1day (Rx1day) and 5-day precipitation (Rx5day) records show decreases through most of the country.

Some western and southeastern stations exhibited increasing index trends (Fig. 13a, b). More than $90 \%$ of the stations have decreased frequency of consecutive wet days (CWD), consistent with CDD findings (Fig. 13c). The largest number of increasing, statistically significant, precipitation trends is found in the simple daily intensity index (SDII) (32 positive;
5 significant), mainly in mountainous areas (Fig. 13d). Wet day precipitation (PRCPTOT) exhibits statistically significant decreases at many stations (Fig. 13e), and heavy precipitation/ very wet days index alterations are spatially coherent. The greatest $\mathrm{R} 10$ and $\mathrm{R} 95 \mathrm{p}$ values are observed along the coastline of Caspian Sea, and time series analysis reveals decreases in both indices, with a steeper negative slope for R95p (Fig. 14a, b). There is significant increase in consecutive dry days especially in the south of Iran (Fig. 14c), and the largest simple daily intensity index (SDII) is observed at the southern Caspian Sea coast (Fig. 14d); however, both time series exhibit a net neutral trend (Fig. 14c, d).

\section{Discussion and conclusions}

Findings in this investigation are consistent with previous studies, as analysis of observational data (Easterling et al.

Table 4 Linear trends ( $\mathrm{mm} /$ decade) of annual, summer, and winter total precipitation in nine different geographic regions of Iran during 1975-2010

\begin{tabular}{llll}
\hline \multirow{2}{*}{ Regions } & \multicolumn{2}{l}{ Trends of total precipitation (mm/decade) } \\
\cline { 2 - 4 } & Winter & Summer & Annual \\
\hline Northwest & -1.12 & -0.17 & -2.20 \\
North & -2.77 & 1.81 & -1.04 \\
Northeast & -5.51 & 0.12 & -0.75 \\
West & -1.49 & 0.13 & -3.34 \\
Central & 0.41 & -0.01 & 0.11 \\
East & 0.04 & 0.02 & -0.55 \\
Southwest & -0.48 & -0.01 & -0.65 \\
South & -0.79 & 0.20 & -0.94 \\
Southeast & -0.78 & -0.04 & -0.43 \\
\hline
\end{tabular}



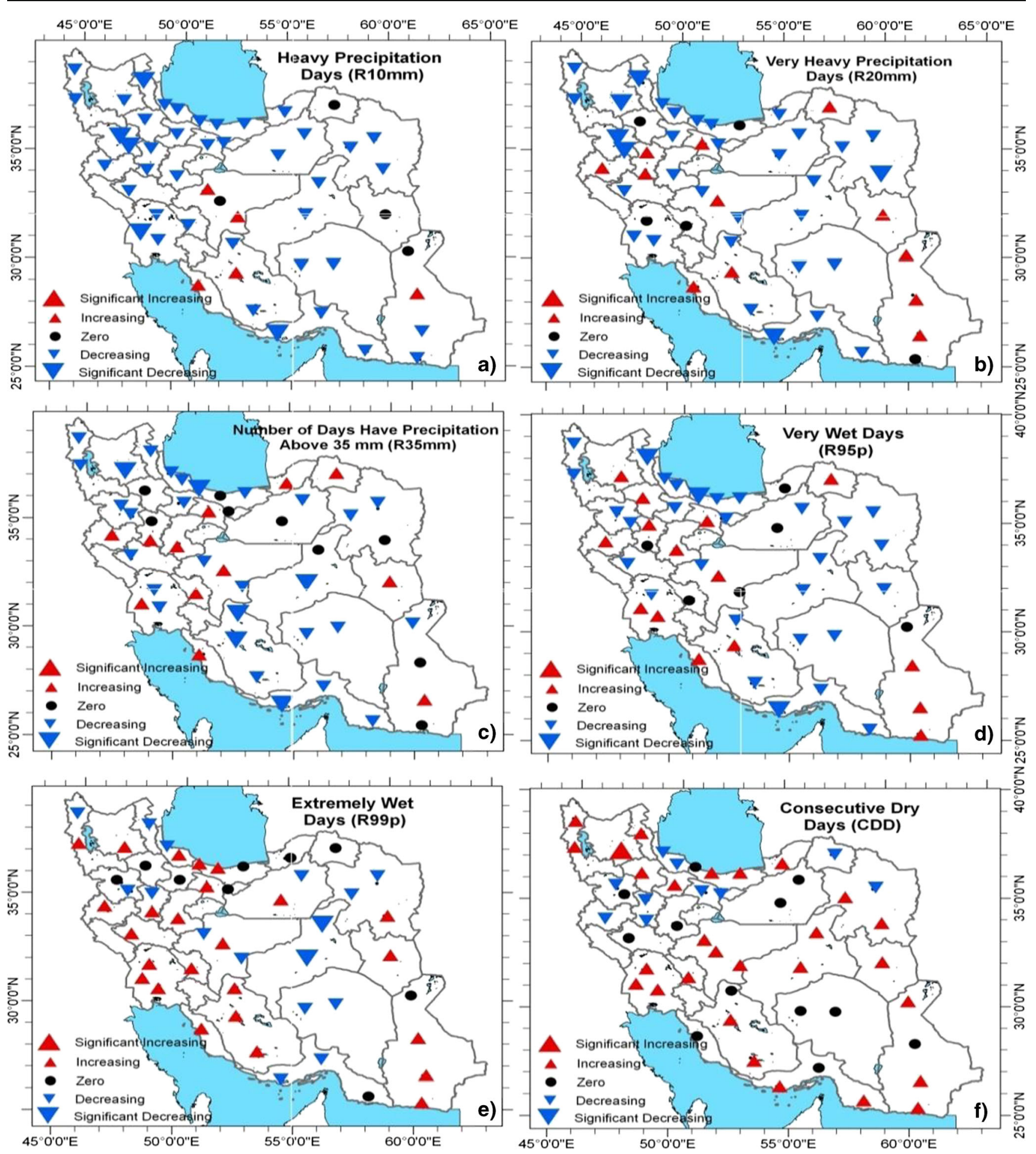

Fig. 12 Same as Fig. 5, but for precipitation extremes including: a heavy precipitation days (R10mm), b very heavy precipitation days (R20mm), $\mathbf{c}$ number of days have precipitation above $35 \mathrm{~mm}(\mathrm{R} 35 \mathrm{~mm})$, d very wet days (R95p), e extremely wet days (R99p), and $\mathbf{f}$ consecutive dry days (CDD)

1997; Alexander et al. 2006) or model data (Kattenberg et al. 1996; Kharin et al. 2007) indicates that warming tendencies are primarily a result of Tmin increases. Research on globally observed changes in daily temperature and precipitation extremes concluded that, between 1951 and 2003, over $70 \%$ of land area sampled had significant increases in annual warm nights and significant decreases in cold night occurrence (Alexander et al. 2006). Most precipitation indices across Iran tend towards drier conditions, while these indices indicated wetter conditions globally. Based on the fifth assessment report of the IPCC (2013), frequency of warm seasonal mean temperatures has rapidly increased 

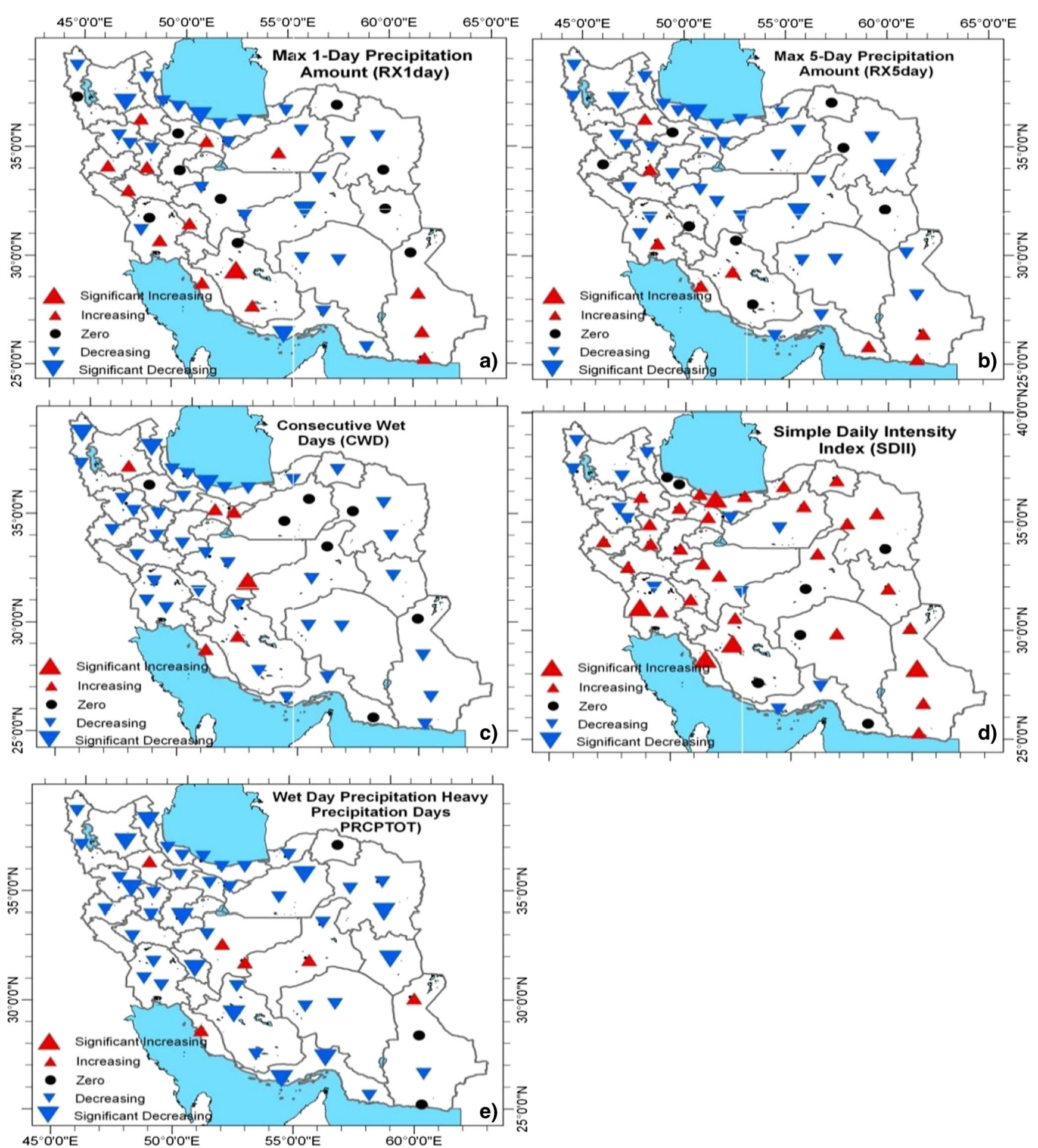

Fig. 13 Same as Fig. 5, but for precipitation extremes including: a max 1-day precipitation amount (RX1day), b max 5-day precipitation amount (RX5day), $\mathbf{c}$ consecutive wet days (CWD), $\mathbf{d}$ simple daily intensity index (SDII), and $\mathbf{e}$ wet day precipitation heavy precipitation days (PRCPTOT)

worldwide (Jones et al. 2008; Stott et al. 2011; Hansen et al. 2012), and these positive trends have been partially attributed to human influence (Stott et al. 2011; Christidis et al. 2012a, 2012b). Vast evidence continues to support the conclusion that, globally, most land areas have experienced significant maximum and minimum temperature extreme warming since the 1950s (Donat et al. 2013c), which is in a good agreement with this study.

Observations show an increase in heavy precipitations at global scale (IPCC 2013), including observed annual maximum 1-day precipitation (RX1day) indicating significant increases in extreme precipitation worldwide. Iran exhibits this 


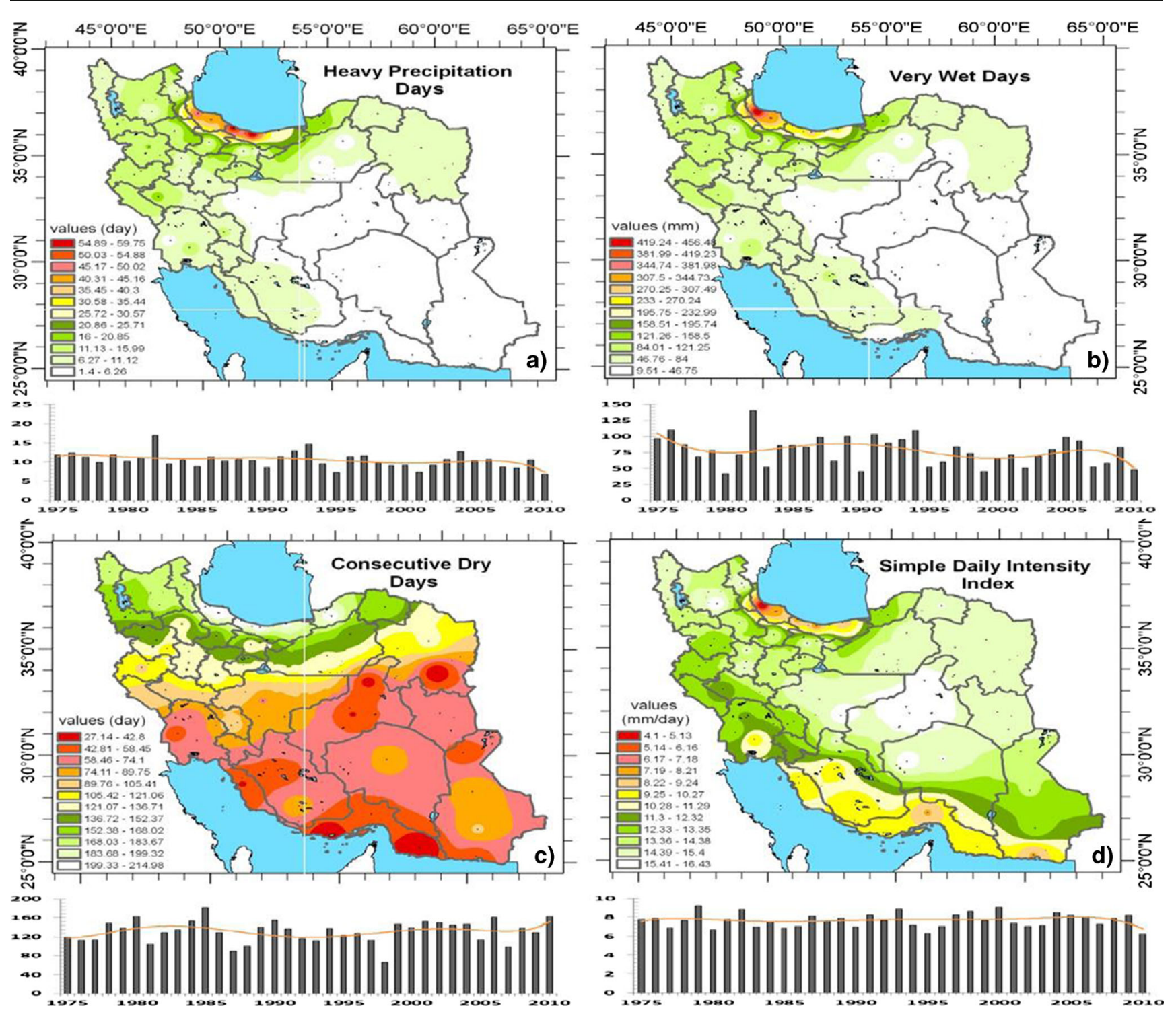

Fig. 14 Same as Fig. 10, but for precipitation indices including a R10 in days, b R95p in mm, c CDD in days, and d SDII in mm/day

trend in some regions, west, southwest, and southeast, but the remainder of the country has a nonsignificant decrease in the RX1day index.

Research on extreme climate characteristics, however, made it possible to reveal regional and seasonal features in the change of extremeness of temperature and precipitation conditions over Iran. In this study, 27 climate extremes indices and their trends were calculated, which provides useful information about changes in extreme climate events across Iran since the mid-1970s. One key result is the spatially and temporally coherent change pattern in extreme temperature events across Iran over the study period, while significant changes in precipitation means and extreme events were observed on most regions of the country. Extremes indices related to minimum temperatures particularly warm nights (TN90p) generally had stronger trends compared to maximum temperatures. Most extreme precipitation indices, however, showed significant trends at a small proportion $(<15 \%)$ of weather stations, with no spatially clustered change patterns.

Elevation changes are slightly (nonsignificantly) correlated with climate extreme indices, notably a positive relationship with frost days (FD) and ice days (ID), which indicate a decreasing trend observed in the mountains. In warm extremes, the correlation is negative for most indices, indicating an ascending trend. The TXx index is an exception with a strongly positive correlation in the Zagros mountain range. The relationship between precipitation extreme trends and elevation indicates a mix pattern, with positive relations in the indices of PRCPTOT, R10mm, and CWD, but the opposite relationship in CDD, R99p, and SDII. Thus, the relationships between climate extremes and elevation are not quite clear.

The annual mean maximum and minimum temperatures across Iran increased by 0.31 and $0.59^{\circ} \mathrm{C} /$ decade, respectively. In winter, rate of increase in maximum and minimum 


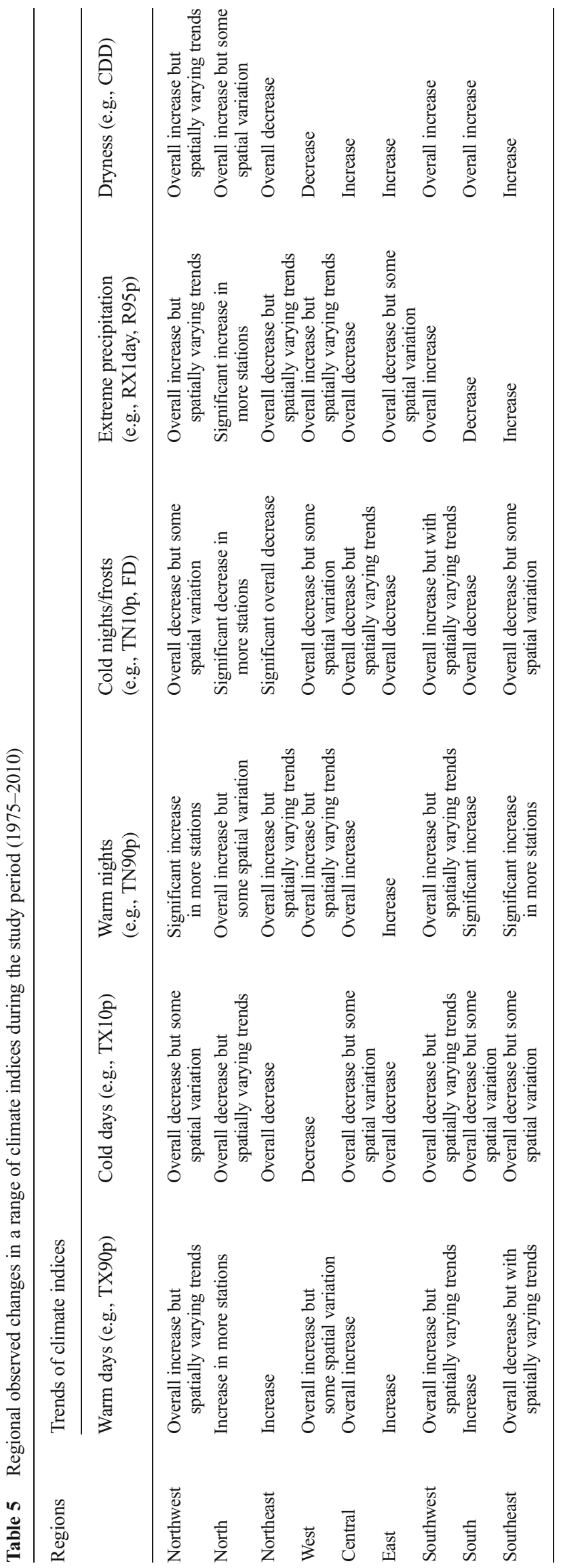

temperatures over the country are 0.054 and $0.071^{\circ} \mathrm{C} /$ decade, respectively, whereas the corresponding increases in summer maximum and minimum temperatures are 0.024 and $0.059{ }^{\circ} \mathrm{C} /$ decade, respectively. Seasonal and annual precipitation does not indicate considerable, spatially coherent trends, unlike the temperature means or extremes in Iran; however, the signs and magnitude of changes in seasonal and annual $\max / \min$ temperature and precipitation events vary spatially. The rates of increase in annual warm day/night frequencies between 1995 and 2010 are nearly double the cold day and night occurrences during this period. The mean of the PDF of cold nights has gradually decreased from more than $20 \%$ in 1975-1986 to less than $15 \%$ in 1999-2010 over the study periods with a reduction in variance, whereas the mean frequency of warm days increased abruptly between the first 12year period (1975-1986) and the recent 12-year period (19992010) from 18 to $40 \%$, respectively, along with increase in the variance.

The change rates of nocturnal extreme temperature events are greater than those of the daytime extreme temperature events, and increasing trends in maximum of maximum temperature $(\mathrm{TXx})$ and maximum of minimum temperature (TNx) extremes occur at many stations over the country. Approximately in 60-70\% of the stations, in summer days (SU) and tropical nights (TR), significant increasing trends were found across the country. Warm nights (TN90p) showed a higher number of positive trends than warm days (TX90p), which more than $95 \%$ of the stations in TN90p indicated significant increasing trends in all over the country (see Tables 5 and 6 for more details).

Warm spell duration indicator (WSDI) increases were identified in parameters including growing season length (GSL), which has a consistent spatial pattern across the country. Cold extreme indices also exhibit trends consistent with warming, i.e., minimum of minimum temperature (TNn) and minimum

Table 6 The most significant trend estimates in a range of climate indices for different regions of Iran during the study period (1975-2010)

Regions Significant trends of climate indices

TX90p TX10p TN90p TN10p RX1day R95p CDD

\begin{tabular}{llllllll}
\hline Northwest & 0.431 & -0.2 & 0.504 & -0.458 & 0.227 & -1.301 & 0.565
\end{tabular}

$\begin{array}{llllllll}\text { North } & 0.255 & -0.256 & 0.633 & -0.534 & -0.518 & -2.267^{\text {a }}\end{array}$

Northeast $0.242 \quad-0.11 \quad 0.611 \quad-0.766^{\text {a }} \quad$ a $\quad$ a

West $\quad 0.582 \quad-0.3850 .276 \quad-0.339$ a $\quad$ a $\quad$ a

$\begin{array}{llllllll}\text { Central } & 0.506 & -0.334 & 0.458 & 0.157 & 0.279 & \text { a } & \text { a }\end{array}$

East $\quad 0.228$ a $\quad 0.273$ a $\quad$ a $\quad$ a $\quad$ a

$\begin{array}{llllllll}\text { Southwest } & 0.288 & -0.175 & 0.669 & -0.783^{\text {a }} & \text { a } & \text { a }\end{array}$

$\begin{array}{llllllll}\text { South } & \text { a } & -0.222 & 0.346 & -0.149 & -1.139 & -2.802 & \text { a }\end{array}$

$\begin{array}{lllllllll}\text { Southeast } & -0.863 & -0.255 & 0.711 & -0.777^{\text {a }} & \text { a } & \text { a }\end{array}$

${ }^{a}$ Indicates that the trend is not statistically significant at $95 \%$ level 
of maximum temperature (TXn) increases. Frost days (FD), ice days (ID), cold nights (TN10p), cold days (TX10p), cold spell duration indicator (CSDI), and diurnal temperature range (DTR) indices have all significantly declined at many stations (see Tables 5 and 6). Comparison of extreme temperature event trends shows that diurnal changes in extreme temperature events in Iran have occurred asymmetrically over the 1975-2010 period, with stronger signals at night than during the day.

Precipitation indices have fewer significant trends in the decrease of amount, frequency, and intensity of precipitation when compared with temperature indices. Ninety percent of stations have a decrease in heavy precipitation days $(\mathrm{R} 10 \mathrm{~mm})$, while very heavy precipitation days (R20mm), days above $35 \mathrm{~mm}(\mathrm{R} 35 \mathrm{~mm})$, and very wet days (R95p) increased nationwide. The number of consecutive dry days (CDD) indicated a nonsignificant increasing trend, while large numbers of R99p in the same regions have been detected. Large numbers of $\max 1$ day (Rx1day) and 5 day precipitation amounts (Rx5day) showed decreasing trends at most stations (see Tables 5 and 6), as well as more than $90 \%$ of the stations indicated decreasing trend in the numbers of consecutive wet days (CWD). In addition, the largest number of increasing and statistically significant trends among precipitation indices was found in the simple daily intensity index (SDII), which mostly located over the mountainous areas. Wet day precipitation (PRCPTOT) also showed statistically significant decreasing trends at many stations of the country.

The signs of changes reported in this study for both temperature and precipitation extreme events are predominantly consistent with earlier findings by Rahimzadeh et al. (2009) for Iran. Compared with their results, however, this study provides more detailed information about the magnitude of seasonal trends and anomalies time series, based on most recent data at a greater number of stations, as well as spatial distributions of trends of extreme temperature and precipitation indices over the country. Changes in the occurrence of extreme indices can often have a far greater detrimental impact on ecosystems than a change in average climate conditions. Determining the precise contribution of climate variation to the frequency of extreme events is not, however, an easy matter. Expected future climate change may continue to alter the frequency and severity of extreme events in various parts of Iran, with its complex climatological regions.

Acknowledgments The authors would like to thank the I.R. of Iran Meteorological Organization (IRIMO) for providing the meteorological data for this study. We also acknowledge support from the Deutsche Forschungsgemeinschaft for the Open Access Publishing Fund of Karlsruhe Institute of Technology.
Open Access This article is distributed under the terms of the Creative Commons Attribution 4.0 International License (http:// creativecommons.org/licenses/by/4.0/), which permits unrestricted use, distribution, and reproduction in any medium, provided you give appropriate credit to the original author(s) and the source, provide a link to the Creative Commons license, and indicate if changes were made.

\section{References}

Aguilar E, Peterson TC, Obando PR, Frutos R, Retana JA, Solera M, Soley J, Gonzalez Garcia I, Araujo RM, Rosa Santos A, Valle VE, Brunet M, Auilar L, Alvarez L, Bautista M, Castaiion C, Herrera L, Ruano E, Sinay JJ, Sanchez E, Hernadez Oviedo GI, Obed F, Salgado JE, Vazquez JL, Baca M, Gutierrez M, Centella C, Espinosa J, Martinez D, Olmedo B, Ojeda Espinoza CE, Nunez R, Haylock M, Benavides H, Mayorga R (2005) Changes in precipitation and temperature extremes in Central America and northern South America, 1961-2003. J Geophys Res. doi:10.1029/ 2005JD006119

Alexander LV, Zhang X, Peterson TC, Caesar J, Gleason B, Tank A, Haylock M, Collins D, Trewin B, Rahimzadeh F, Tagipour A, Kumar KR, Revadekar J, Griffiths G, Vincent L, Stephenson DB, Burn J, Aguilar E, Brunet M, Taylor M, New M, Zhai P, Rusticucci M, Vazquez-Aguirre JL. (2006) Global observed changes in daily climate extremes of temperature and precipitation. J Geophys ResAtmos 111(D5). doi:10.1029/2005jd006290

Alexander LV, Hope P, Collins D, Trewin B, Lynch A, Nicholls N (2007) Trends in Australia's climate means and extremes: a global context. Aust Meteorol Mag 56(1):1-18

Alijani B (1996) Climate of Iran. Payame Nour University press, Tehran (in Persian)

Alijani B. (2007) Time series analysis of daily rainfall variability and extreme events., 10th International Meeting on Statistical Climatology, Beijing, China

Brunetti M, Buffoni L, Maugeri M, Nanni T (2000) Precipitation intensity trends in northern Italy. Int J Climatol 20:1017-1031

CCSP (2008) Weather and climate extremes in a changing climate., regions of focus: North America, Hawaii, Caribbean, and U.S. Pacific Islands. A report by the U.S. climate change science program and the subcommittee on global change research., [Thomas R. Karl, Gerald A. Meehl, Christopher D. Miller, Susan J. Hassol, Anne M. Waple and William L. Murray (eds.)]. Department of Commerce, NOAA's National Climatic Data Center, Washington, D.C., USA, 164 pp. Available from http://www.climatescience.gov/Library/sap/ sap3-3/final-report/sap3-3-final-all.pdf

Choi, G., Collins, D., Ren, G., Trewin, B., Baldi, M., Fukuda, Y., Afzaal, M., Pianmana, T., Gomboluudev, P., Huong, PTT., Lias, N., Kwon, W. T., Boo, K. O., Cha, Y. M., Zhouc, Y. (2009) Changes in means and extreme events of temperature and precipitation in the AsiaPacific network region, 1955-2007. Int J Climatol 2009, 29:19061925. doi:10.1002/joc.1979.

Christidis N, Stott PA, Zwiers FW, Shiogama H, Nozawa T (2012a) The contribution of anthropogenic forcings to regional changes in temperature during the last decade. Clim Dyn 39:1259-1274

Christidis N, Stott PA, Jones GS, Shiogama H, Nozawa T, Luterbacher J (2012b) Human activity and anomalously warm seasons in Europe. Int J Climatol 32:225-239

Das HP, Adamenko TI, Anaman KA, Gommes RG, Johnson G. (2003) Agrometeorology related to extreme events. World Meteorological Organization, Technical Note No 201

Domonkos P (2001) Temporal accumulations of extreme daily mean temperature anomalies. Theor Appl Climatol 68:17-32 
Donat MG et al. (2013c) Updated analyses of temperature and precipitation extreme indices since the beginning of the twentieth century: the HadEX2 dataset. J Geophys Res Atmos 118:2098-2118

Dos Santos CAC, Neale CMU, Rao TVR, Da Silva BB (2010) Trends in indices for extremes in daily temperature and precipitation over Utah USA. Int J Climatol. doi:10.1002/joc.2205

Easterling DR, Horton B, Jones PD, Peterson TC, Karl TR, Parker DE, Salinger MJ, Razuvayev V, Plummer N, Jamason P, Folland CK (1997) Maximum and minimum temperature trends for the globe. Science 277:364-367

Easterling DR, Alexander LV, Mokssit A, Detemmerman V (2003) CCL/ CLIVAR workshop to develop priority climate indices. Bull Amer Meteorol Soc 84:1403-1407

Frei C, Schär C (2001) Detection probability of trends in rare events: theory and application to heavy precipitation in the Alpine Region. J Climate 14:1568-1584

Frich P, Alexander LV, Della-Marta P, Gleason B, Haylock M, Klein Tank AMG, Peterson T (2002) Observed coherent changes in climatic extremes during the second half of the twentieth century. Clim Res 19:193-212

Groisman PY, Karl TR, Easterling DR, Knight RW, Jamason PF, Hennessy KJ, Suppiah R, Page CM, Wibig J, Fortuniak K, Razuvaev VN, Douglas A, Forland E, Zhai PM (1999) Changes in the probability of heavy precipitation: important indicators of climatic change. Clim Chang 42:243-283

Hansen J, Sato M, Ruedy R (2012) Perception of climate change. Proc Natl Acad Sci U S A 109:E2415-E2423

Haylock MR, Peterson TC, Alves LM, Ambrizzi T, Anunciacao MT, Baez J, Barros VR, Berlato MA, Bidegain M, Coronel G, Corradi V, Garcia VJ, Grimm AM, Karoly D, Marengo JA, Marino MB, Moncunill DF, Nechet D, Quintana J, Rebello E, Rusticucci M, Santos JL, Trebejo I, Vincent LA (2006) Trends in total and extreme South American rainfall in 1960-2000 and links with sea surface temperature. J Clim 19:1490-1512

Hedayat Dezfuly A (2001) Analysis on changes in starting date of precipitation and its trend in Tehran. Research Institute of Meteorology of Tehran, Tehran(in Persian)

Hirschi M, Seneviratne SI, Alexandrov V, Boberg F, Boroneant C, Christensen OB, Formayer H, Orlowsky B, Stepanek P (2011) Observational evidence for soil-moisture impact on hot extremes in southeastern Europe. Nat Geosci. doi:10.1038/NGEO1032

Huynen MMTE, Martens P, Schram D, Weijenberg MP, Kunst AE (2001) The impact of heat waves and cold spells on mortality rates in the Dutch population. Environ Health Perspect 109: $463-470$

Insaf TZ, Lin S, Sheridan SC (2012) Climate trends in indices for temperature and precipitation across New York State, 1948-2008. Air Qual Atmos Health. doi:10.1007/s11869-011-0168-x

IPCC (2013) Climate change 2013: the physical science basis. contribution of working group $\mathrm{i}$ to the fifth assessment report of the intergovernmental panel on climate change [Stocker, T.F., D. Qin, G.-K. Plattner, M. Tignor, S.K. Allen, J. Boschung, A. Nauels, Y. Xia, V. Bex and P.M. Midgley (eds.)]. Cambridge University Press, Cambridge, United Kingdom and New York, NY, USA, 1535pp.

Jones PD, Norton EB, Folland CK, Hulme M, Parker DE, Basnett TA (1999) The use of indices to identify changes in climatic extremes Clim. Change 42:131-149

Jones, P. D., D. H. Lister, and Q. Li, 2008: Urbanization effects in largescale temperature records, with an emphasis on China. J Geophys Res Atmos, 113, D16122.

Karl TR et al. (1995) Trends in high-frequency climate variability in the 20th-century. Nature 377:217-220

Karl TR, Knight RW (1998) Secular trends of precipitation amount, frequency, and intensity in the United States. Bull Amer Meteor Soc 79:1107-1119
Karl TR, Nicholls N, Ghazi A (1999) CLIVAR/GCOS/WMO workshop on indices and indicators for climate extremes., workshop summary. Clim Chang 42:3-7

Kattenberg A, Giorgi F, Grassl H, Meehl GA, Mitchell JFB, Stouffer RJ, Tokioka T, Weaver AJ, Wigley TML (1996) Climate models - projections of future climate. In: Houghton JT, Filho LGM, Callander BA, Harris N, Kattenberg A, Maskell K (eds) Climate change (1995) the science of climate change. Cambridge University Press, Cambridge and New York, p. 572

Kavyani M, Asakereh H (1999) Investigation of Isfahan annual precipitation. Department of Geography, Isfahan and Zanjan University, Zanjan(in Persian)

Kharin, V. V., Zwiers, F. W., Zhang, X., Hegerl, G. C. (2007) Changes in temperature and precipitation extremes in the IPCC ensemble of global coupled model simulations, J Climate, 20, 15 April, 2007., DOI: 10.1175/JCLI4066.1

Kioutsioukis I, Melasa D, Zerefos C (2010) Statistical assessment of changes in climate extremes over Greece (1955-2002). Int J Climatol 30:1723-1737

Klein Tank AMG, Können GP (2003) Trends in indices of daily temperature and precipitation extremes in Europe, 1946-1999. J Climate 16:3665-3680

Kiktev D et al. (2003) Comparison of modeled and observed trends in indices of daily climate extremes. J Clim 16:3560-3571

Manton MJ, Della-Marta PM, Haylock MR, Hennessy KJ, Nicholls N, Chambers LE, Collins DA, Daw G, Finet A, Gunawan D, Inape K, Isobe $\mathrm{H}$, Kestin TS, Lefale P, Leyu CH, Lwin T, Maitrepierre L, Ouprasitwong N, Page CM, Pahalad J, Plummer N, Salinger MJ, Suppiah R, Tran VL, Trewin B, Tibig I, Yee D (2001) Trends in extreme daily rainfall and temperature in southeast Asia and the South Pacific: 1961-1998. Int J Climatol 21:269-284

Marofi S, Sohrabi MM, Mohammadi K, Sabziparvar AA, Zare-Abyaneh $H$ (2010) Investigation of meteorological extreme events over coastal regions of Iran. Theor Appl Climatol 103:401-412. doi:10.1007/ s00704-010-0298-3

Moberg A, Jones PD (2005) Trends in indices for extremes in daily temperature and precipitation in central and western Europe, 1901-1999. Int J Climatol 25:1149-1171

Moonen AC, Ercoli L, Mariotti M, Masoni A (2002) Climate change in Italy indicated by agrometeorological indices over 122 years. Agric Forest Meteor 111:13-27

New M, Hewitson B, Stephenson DB et al. (2006) Evidence of trends in daily climate extremes over southern and west Africa. J Geophys Res Atmos 111:D14102. doi:10.1029/2005JD006289

Nicholls, M., Gruza, G.W., Jouzel, J., Karl, T.R., Ogallo, L.A., and Parker, D.E. (1996) Chapter 3, observed climate variability and change., In: Climate change 1995: the science of climate change. Contribution to Working Group I to IPCC SAR. (eds.: J.T. Houghton et al.) Cambridge Univ. Press,137-192.

Osborn TJ, Hulme M, Jones PD, Basnett TA (2000) Observed trends in the daily intensity of United Kingdom precipitation. Int J Climatol 20:347-364

Peterson TC. (2005) The workshop on enhancing South and Central Asian Climate monitoring and indices. Pune, India, February 14 19, 2005, CLIVAR Exchanges 10(2):6.

Peterson TC, Zhang XB, Brunet-India M et al. (2008) Changes in North American extremes derived from daily weather data. J Geophys Res Atmos 113:D07113. doi:10.1029/2007JD009453

Plummer N, Salinger MJ, Nicholls N, Suppiah R, Hennessy KJ, Leighton RM, Trewin B, Page CM, Lough JM (1999) Change in climate extremes over the Australian region and New Zealand during the twentieth century. Clim Change 42:183-202

Rahimzadeh, F., Asgari, A., Fattahi, E. (2009) Variability of extreme temperature and precipitation in Iran during recent decades., Int. J. Climatol. 29: 329-343 (2009) 
Sabziparvar AA, Mirmasoudi SH, Tabari H, Nazemosadatb MJ, Maryanajic Z (2011) ENSO teleconnection impacts on reference evapotranspiration variability in some warm climates of Iran. Int J Climatol 31:1710-1723

Sen Roy S, Balling RC (2004) Trends in extreme daily precipitation indices in India. Int J Climatol 24:457-466

Sohrabi M.M., Marofi S, and Ababaei B. (2009) Investigation of temperature and precipitation indices by using RClimDex and R software in Semnan province., International Conference on Water Resources, 16-18 August, pp 341-348.

Sohrabi MM, Ryu JH, Abatzoglou J, Tracy J (2013a) Climate extreme and its linkage to regional drought over Idaho, USA. J Nat Hazards 6(1):653-681

Sohrabi MM, Ryu JH, Alijani B (2013b) Spatial and temporal analysis of climatic extremes over the mountainous regions of Iran. Int Climate Chang 4(4):19-36

Stott PA, Jones GS, Christidis N, Zwiers FW, Hegerl G, Shiogama H (2011) Single-step attribution of increasing frequencies of very warm regional temperatures to human influence. Atmos Sci Lett $12: 220-227$

Souvignet M, Laux P, Freer J, Cloke H, Thinh DQ, Thuc T, Cullmann J, Nauditt A, Flügel WA, Kunstmann H, Ribbe L (2014) Recent climatic trends and linkages to river discharge in Central Vietnam. Hydrol Process 28:1587-1601. doi:10.1002/hyp.9693

Taghavi, F. (2010) Linkage between climate change and extreme events in Iran, J Earth Space Physics. Vol. 36, No. 2, 2010, P. 33-43

UNEP (United Nations Environmental Programme) (2004) Impacts of summer 2003 heat wave in Europe. Environ Alert Bull 2:1-3

Vincent LA et al. (2005) Observed trends in indices of daily temperature extremes in South America 1960-2000. J Clim 18(23):5011-5023

Wong MC, Mok HY, Lee TC (2010) Observed changes in extreme weather indices in Hong Kong. Int J Climatol. doi:10.1002/joc.2238

Zhang X, Yang F. 2004. RClimDex (1.0) user manual., (Available at http://cccma.seos.uvic.ca/ETCCDMI/software.shtml)

Zhang XB, Hegerl G, Zwiers FW, et al. (2005) Avoiding inhomogeneity in percentile-based indices of temperature extremes. J Climatol 18(11):1641-1651

Zhang, X, Alexander, L., Hegerl G. C., Jones, P., Tank, A. K., Peterson, C. T., Trewin, B., Zwiers, F. W. (2011) Indices for monitoring changes in extremes based on daily temperature and precipitation data. WIREs Clim Change 2011. doi: 10.1002/wcc.147.

Zong Y, Chen X (2000) The 1998 flood on the Yangtze, China. Nat Hazards 22:165-184 